ARCHIWA - KanCELARIE - ZBIORY

NR 2 (4)/2011

Marcin Hlebionek

Uniwersytet Mikotaja Kopernika w Toruniu

\title{
O PIECZECIACH STAROSTY GENERALNEGO WIELKOPOLSKI Adama Sędziwoja Czarnkowskiego
}

\author{
Kto takowym kleinotem z Olimpu iasnego \\ Nalenczem dom Adama uczciet Czarnkowskiego \\ Tym znać dawat, że pokąd Korona schorzata \\ Data się mu obwiiać, zdrowa zostawata ${ }^{1}$.
}

Aldam Sędziwój Czarnkowski wywodził się z wielkopolskiej rodziny szla-

${ }^{1}$ J. Choryński, Wieczność slawy y nieśmiertelny Pamiątki Jaśnie Wielmożnego Jego Mości Pana Adama Sędziwoia Czarnkowskiego, wojewody Eęnczyckiego Generata Wielgopolskiego, Miedzyrzeckiego, Pysdrskiego etc. Starosty, Poznań 1628, s. a1.

2 J. Pakulski, Natęcze wielkopolscy wśredniowieczu, Toruń 1982, s. 54-68; K. Górska-Gołaska, Dobra Natęczów w Wielkopolsce wśredniowieczu, Studia i Materiały do Dziejów Wielkopolski i Pomorza, t. 14, z. 2, 1984, s. 192; ostatnio: Z. Górczak, Rozwój majątku rodziny Czarnkowskich herbu Natęcz w XV i początkach XVI wieku, [w:] Cognitioni gestorum. Studia z dziejów średniowiecza dedykowane Profesorowi Jerzemu Strzelczykowi, red. D. A. Sikorski, A. M. Wyrwa, Warszawa 2006, s. 505; tenże, Rozwój majątków możnowtadztwa wielkopolskiego w II potowie XV i poczatkach XVI wieku, Poznań 2007, s. 180; o karierach członków rodziny na przełomie XVI i XVII w. zob. E. Opaliński, Rodziny wielkosenatorskie w Wielkopolsce, na Kujawach i na Mazowszu za Zygmunta III, Warszawa 2007, s. 233-237. 
Był przedstawicielem jej młodszej linii, zapoczątkowanej przez Sędziwoja Czarnkowskiego, kasztelana przemęckiego (jego brat Maciej uchodzi za protoplastę linii starszej), syna Sędziwoja, wojewody poznańskiego, a wnuka Jana, kasztelana gnieźnieńskiego ${ }^{3}$. Adam był wnukiem owego Sędziwoja, synem Wojciecha Sędziwoja Czarnkowskiego, starosty generalnego Wielkopolski, i Jadwigi z Gulczewa Sierpskiej herbu Prawdzic, wojewodzianki rawskiej. Za zasługi w wojnach z Moskwą już w 1579 r. król Stefan Batory nagrodził go nominacją na urząd starosty pyzdrskiego. Równocześnie odziedziczył on po ojcu godność komandora poznańskich joannitów. Za panowania Zygmunta III należał do stronników monarchy. Właśnie za czasów pierwszego Wazy rozkwitła jego kariera: w 1593 r. otrzymał starostwo generalne Wielkopolski ${ }^{4}$, w 1606 r. zaś województwo łęczyckie ${ }^{5}$. Poza tym nadal podlegało mu starostwo pyzdrskie oraz wiele pomniejszych królewszczyzn. Adama Czarnkowskiego znano też jako fundatora kościołów i klasztorów. Będąc właścicielem kilku miast oraz kilkudziesięciu wsi, należał do grona najbogatszych magnatów wielkopolskich swoich czasów ${ }^{6}$.

Mimo roli, jaką odegrał sam Adam Sędziwój Czarnkowski, jak i cała jego rodzina, w dziejach Wielkopolski, ani heraldyka, ani sfragistyka Nałęczów-Czarnkowskich nie zainteresowały dotąd badaczy. Pewne rozproszone informacje na temat odmiany herbu tego rodu można znaleźć w herbarzach przygotowanych przez Józefa Szymańskiego ${ }^{7}$. Znacznie więcej uwagi poświęcono dziejom samego herbu Nałęcz, którego odmianą posługiwali się Czarnkow-

3 W. Dworzaczek, Genealogia, Warszawa 1959, tabl. 106.

4 Urzędnicy wielkopolscy XVI-XVIII w. Spisy, oprac. A. Bieniaszewski, Wrocław 1987, s. 165, nr 1186; nadanie Czarnkowskiemu generalstwa wielkopolskiego i tekst jego przysięgi publikuje J. Bielecka, Kancelaria grodzka wielkopolska, Studia Źródłoznawcze, t. 1, 1957, s. 145, nr 13.

5 Urzędnicy województw tęczyckiego i sieradzkiego XVI-XVIII wieku. Spisy, oprac. E. Opaliński, H. Żerek-Kleszcz, red. A. Gąsiorowski, Kórnik 1993, s. 99, nr 628.

6 W. Dobrowolska, Adam Sędziwój Czarnkowski, [w:] Polski stownik biograficzny, t. 4, Kraków 1938, s. 214-215; M. B. Topolska, Czarnkowski Adam Sędziwój, [w:] Wielkopolski stownik biograficzny, Warszawa-Poznań 1982, s. 126; E. Opaliński, Elita wtadzy w województwach poznańskim i kaliskim za Zygmunta III, Poznań 1981, s. 56; tenże, Rodziny, s. 236-237.

7 J. Szymański, Herbarz średniowiecznego rycerstwa polskiego, Warszawa 1993, s. 192-195; tenże, Herbarz rycerstwa polskiego z XVI w., Warszawa 2001, s. 185-187, tam też wcześniejsza literatura. 
scy ${ }^{8}$. Gorzej wygląda sytuacja, jeśli chodzi o badania nad sfragistyką szlachecką w ogóle, a w szczególności odnoszącą się do interesującej nas rodziny. Niedawno problematykę pieczęci używanych przez starostów grodzkich podjęli Janusz Łosowski oraz Marek Adamczewski'. Stan najnowszych badań nad nowożytnymi pieczęciami szlacheckimi (głównie prywatnymi) podsumował Wojciech Strzyżewski w książce poświęconej nowożytnym pieczęciom szlachty księstwa głogowskiego ${ }^{10}$. Jednak jego ustalenia, które dotyczą regionu znajdującego się poza granicami dawnej Rzeczypospolitej, mającego własną specyfikę ustrojową, należy odnosić do warunków polskich z dużą ostrożnością. Pomimo tego jest to, jak na razie, najpełniejsze studium analizujące pieczęcie używane przez szlachtę w ogólności.

Poniższe rozważania składają się z trzech części. W pierwszej zostały omówione zagadnienia związane z rekonstrukcją systemu sfragistycznego Adama Sędziwoja Czarnkowskiego, a w drugiej - odnoszące się do systemu informacyjnego jego pieczęci. Wreszcie w części trzeciej, dla której wcześniejsze analizy pieczęci Adama Sędziwoja Czarnkowskiego stanowią inspirację, został poruszony problem pieczęci jako nośnika pamięci historycznej.

\section{System sfragistyczny Adama Sędziwoja Czarnkowskiego}

Do tej pory udało się odnaleźć dziewięć rodzajów pieczęci używanych przez Adama Sędziwoja Czarnkowskiego. Ich odciski pochodzą z okresu po 1593 r., a więc czasu, kiedy Czarnkowski, zdobywając urząd starosty generalnego, wspiął się na szczyty swej kariery. Niewątpliwie pieczęciami posługiwał się również wcześniej, lecz ze względu na mniejsze znaczenie osoby dysponu-

${ }^{8}$ F. Piekosiński, Heraldyka polska wieków średnich, Kraków 1899, s. 101-103; J. Pakulski, dz. cyt., s. 18-20; próbę systematyzacji dziejów herbu Nałęcz podjął J. Łojko, Średniowieczne herby polskie, Poznań 1985, s. 35-41.

9 J. Łosowski, Pieczęcie starostów chetmskich od drugiej potowy XVI do XVIII w., [w:] Pieczęć w Polce średniowiecznej i nowożytnej, red. P. Dymmel, Lublin 1998, s. 147-170; w tym samym tomie znajduje się katalog pieczęci tychże starostów, zob. tenże, Katalog pieczęci starostów chetmskich od drugiej potowy XVI do XVIII w., [w:] Pieczęć w Polsce, s. 171-192; M. Adamczewski, Pieczęcie urzędowe wtadz lokalnych z obszaru Polski centralnej, cz. 2: Pieczęcie sądów szlacheckich do 1793 r., Łódź 2010, s. 6-41.

${ }_{10}$ W. Strzyżewski, Herby i tytuty. Pieczęć szlachecka w księstwie gtogowskim XVI-XVIII w., Warszawa 2009, s. 5-7, tam wcześniejsza literatura; dla pieczęci rycerskich badania podsumował J. Wroniszewski, Średniowieczne pieczęcie rycerstwa polskiego, [w:] Pieczęcie w dawnej Rzeczypospolitej, red. Z. Piech, J. Pakulski, J. Wroniszewski, Warszawa 2006, s. 235-250. 
jącej nimi są one trudniej uchwytne. Nie mogły jednak istotnie różnić się od sigillów używanych przez najbliższych krewnych Adama Sędziwoja, piastujących godności podobnego szczebla.

Najstarsze znane odciski pieczęci Adama Sędziwoja pochodzą z około 1596 r., choć typariusz, którym zostały wykonane, sporządzono zapewne trzy lata wcześniej. Uwierzytelniają one ekstrakty z ksiąg grodu kaliskiego wystawione po 1596 i 1606 r. ${ }^{11}$ Są dość duże, ich średnica wynosi bowiem $40 \mathrm{~mm}$, a wyobrażają w polu pieczęci, oddzielonym od pola legendy ciągłą linią, renesansową tarczę z herbem Nałęcz, w charakterystycznej dla Czarnkowskich odmianie: $\mathrm{z}$ niewiązaną pomłością. Tarcza zachodzi na pole legendy, dzieląc inskrypcję napieczętną. W klejnocie umieszczono, między dwoma jelenimi rogami, pawi ogon przeszyty z lewa w skos strzałą. Pole pieczęci, z obu stron hełmu i tarczy, wypełniają labry, a poniżej nich znajdują się rozdzielone tarczą dwie litery: D//C. Legenda pieczęci, którą można zrekonstruować na podstawie zachowanych odcisków, brzmi: *ADAM. SANDI(voius). A. CZARNKOW. MAI//OR(is). POL(oniae). GEN(eralis). ET. PISDR(ensis). CAP(itaneus). 1593.

Źródła potwierdzają równoczesne używanie przez magnata dwóch innych pieczęci. Odciski pierwszej z nich pochodzą również z lat dziewięćdziesiątych XVI w. Zachowały się one na szczególnie okazałym ekstrakcie z ksiąg grodu poznańskiego, zawierającym potwierdzenie aktu sprzedaży Poznaniowi jednej z kamienic ${ }^{12}$, oraz w liście skierowanym do książąt szczecińskich ${ }^{13}$. Mimo rozmiarów zbliżonych do poprzedniej (średnica $41 \mathrm{~mm}$ ), ta pieczęć ma bardziej rozbudowaną ikonografię. W jej polu, oddzielonym od legendy ciągłą linią, wyobrażono tarczę ze skwadrowanymi herbami Nałęcz, w odmianie używanej przez Czarnkowskich, i Poronia. Nad tarczą znajdują się dwa zwrócone ku sobie hełmy - pierwszy jest zwieńczony opisanym wyżej klejnotem, z tym że strzała przeszywająca pióropusz jest skierowana w skos, drugi zaś to pawi ogon między dwoma bawolimi rogami, zakończonymi proporczykami. Oba klejnoty dzielą pole legendy. Z każdej strony tarczę podtrzymują wspięte gryfy, nad którymi, jak i pomiędzy klejnotami, rozłożono labry. Biegnąca wokół wyobrażenia inskrypcja napieczętna (odtworzona na podstawie zacho-

11 Archiwum Diecezjalne we Włocławku (dalej: ADiec we Włocławku), Zbiór dokumentów (dalej: Zd), sygn. 1757, 1760.

12 Archiwum Państwowe w Poznaniu (dalej: AP w Poznaniu), Akta miasta Poznania 1254-1945 (dalej: AMP), sygn. D 494.

13 Archiwum Państwowe w Szczecinie (dalej: AP w Szczecinie), Archiwum Książąt Szczecińskich [1209] 1354-1831 (dalej: AKS), sygn. I/542, luźny odcisk po k. 155. 
wanych egzemplarzy) brzmiała: *ADAM -SAD(ivoius): A CZAR(nkow): MA$\mathrm{I}($ oris). $/ / \cdot \mathrm{PO}[L] \mathrm{O}$ (niae): GE[...CAP]IT(aneus) 1593.

Trzeci typ pieczęci używanych wówczas przez Adama Sędziwoja jest znany ze znacznie późniejszego odcisku, wykonanego w $1620 \mathrm{r}^{14}$ Podobnie jak pieczęcie „kaliskie”, jest to sigillum wyobrażające jednopolową, renesansową tarczę z Nałęczem Czarnkowskich, nad którą znajduje się hełm z labrami i klejnotem: pawim ogonem przeszytym z lewa w skos strzałą, między jelenim porożem. Odcisk ma $41 \mathrm{~mm}$ średnicy. Legenda, na której pole zachodzi tarcza herbowa, brzmi: *ADAM. SAND(ivoius): A. CZARNKOW MA//IO(ris): POL(oniae). GEN(eralis). ET PISDR(ensis). CAP(itaneus). 1593. Wcześniejszej chronologii tej pieczęci dowodzą znajdująca się na stemplu data oraz tytulatura umieszczona w legendzie, pomijająca piastowaną przez Czarnkowskiego od 1606 r. godność wojewody łęczyckiego. Właśnie otrzymanie palacji łęczyckiej spowodowało wymianę pieczęci dotąd używanych przez magnata. Stało się to zapewne w 1606 r., na co wskazują daty umieszczone na stemplach pieczętnych, a także fakt, że ekstrakty z grodu kaliskiego datowane na 1606 r. są opatrzone pieczęciami zarówno ze starszą, jak i nową tytulaturą.

Z okresu po 1606 r. znamy odciski sześciu odmian pieczęci Adama Sędziwoja Czarnkowskiego. Nie można jednak wykluczyć, że przynajmniej jedna z nich powstała i była używana również w okresie wcześniejszym. Zachowane odciski tego ostatniego sigillum pochodzą z $1606^{15}$ i 1607 r. ${ }^{16}$ Jest ono okrągłe i stosunkowo nieduże $(24 \mathrm{~mm})$. Wizerunek umieszczony w polu pieczęci przedstawia renesansową tarczę z godłem herbu Nałęcz Czarnkowskich, w klejnocie zaś przeszyty strzałą z lewa w skos pawi ogon, między dwoma jelenimi rogami. Herb dzieli u dołu i u góry słabo czytelną legendę. Wyraźniejszy jest jedynie jej początek, zawierający imię dysponenta: ADAM[...].

Wspomniano już, że z okresu po 1606 r. pochodzi opieczętowany ekstrakt z ksiąg grodu kaliskiego. Uwierzytelniający go odcisk ma $39 \mathrm{~mm}$ średnicy, jest więc nieco mniejszy od wcześniejszych pieczęci. Ikonografią nie różni się od poprzednich, choć ze względu na zły stan zachowania trudno powiedzieć, czy na nim również znajdują się charakterystyczne sygle D//C. Różnice są natomiast widoczne w treści inskrypcji napieczętnej, mimo że nie zachowała się ona w całości. Czytelne jej fragmenty brzmią: ADAM S[...A CZARNK]OW PAL//[...]CAP [...] $]^{17}$. Dokonano więc aktualizacji tytulatury, wprowadzając

${ }^{14}$ Tamże, sygn. I/537, k. 190v.

15 Tamże, sygn. I/535, k. 11v.

16 AP w Poznaniu, AMP, sygn. D 151.

${ }^{17}$ AP w Poznaniu, Majątek Konarzewo 1644-1936 (dalej: MK), sygn. 2385, k. 2v. 
do napisu informację o piastowanej przez Czarnkowskiego godności wojewody łęczyckiego. Z podobnym zabiegiem mamy do czynienia na kolejnych pieczęciach Adama Sędziwoja.

Z lat 1610-1624 pochodzą liczne odciski pieczęci wyobrażającej podtrzymywaną przez gryfy tarczę ze skwadrowanym Nałęczem Czarnkowskich i Poronią, zwieńczoną dwoma hełmami z właściwymi herbom klejnotami. Ma ona wymiary zbieżne z podobnym sigillum używanym przed $1605 \mathrm{r}$.: jej średnica wynosi $41 \mathrm{~mm}^{18}$. Zmiany zaszły natomiast w inskrypcji napieczętnej, do której, podobnie jak we wcześniej opisanym przypadku, włączono tytulaturę wojewodzińską. Zrekonstruowana na podstawie lepiej zachowanych egzemplarzy legenda tej pieczęci brzmi: ADAM SADIW(oius) A CZARN(kow) PAL(atinus)//LANC(iciensis) MAI(oris) PO(loniae): GEN(eralis) CA$\mathrm{P}$ (itaneus) PIS(drensis) 1606.

Z 1616 r. pochodzi odcisk wykonanej równocześnie bardziej okazałej wersji tego sigillum ${ }^{19}$. Pieczęć mierzy $45 \mathrm{~mm}$ średnicy. Jej ikonografia jest analogiczna do wyżej opisanej, także legenda ma zbliżoną do niej treść: ADAM SAD(ivoius) A CZA[...] PAL(atinus)//LANC(iciensis) MAI(oris): PO(loniae): GE(neralis): PIS(drensis) CA(pitaneus) 1606.

Również na 1606 r. można datować kolejną pieczęć Adama Sędziwoja, tym razem wyobrażającą tarczę jednopolową, zachodzącą u dołu na pole legendy, z używaną przez Czarnkowskiego odmianą herbu Nałęcz i klejnotem. Pole pieczęci z obu stron tarczy wypełniają labry. Niżej znajduje się, rozdzielona tarczą, data [10]//06. Jej ikonografia wykazuje zatem podobieństwo do wyżej opisanych pieczęci „kaliskich” oraz pieczęci starszego typu znanej z odcisku wykonanego w 1620 r. Jedyną różnicą jest umieszczenie daty w polu pieczęci, nie zaś, jak we wcześniejszych przypadkach, w polu legendy. Sama inskrypcja jest, niestety, źle zachowana. Jej czytelne fragmenty brzmią: [ADAM SAN] DIV[...A CZARNK]OW PA(latinus)//[...]MAI(oris) PO(loniae) GEN[...] ${ }^{20}$.

Przegląd sfragistycznej spuścizny starosty generalnego Wielkopolski zakończy pieczęć, której odcisk został wykonany w 1627 r., a więc niedługo przed śmiercią magnata ${ }^{21}$. Rzeczywiście zdaje się ona najmłodsza z całego zbioru.

18 AP w Szczecinie, AKS, sygn. I/537, k. 192v; I/603, k. 206v, k. 262v; Archiwum Państwowe we Wrocławiu (dalej: AP we Wrocławiu), Księstwo Oleśnickie 1320-1862 (dalej: KsO), rep. 33, sygn. 806, s. 126, k. 149, k. 161, k. 231.

19 AP w Szczecinie, AKS, sygn. I/537, k. 126v, odcisk z 1616 r.

20 AP we Wrocławiu, KsO, rep. 33, sygn. 806, k. 412; identyczna jest pieczęć uwierzytelniająca ekstrakt wpisu dokonanego w 1603 r. do ksiąg grodzkich poznańskich: AP w Poznaniu, MK, sygn. 2385.

21 AP w Szczecinie, AKS, sygn. I/538, k. 3v. 
To owalne sigillum o wymiarach $28 \times 23 \mathrm{~mm}$ wykazuje cechy właściwe barokowym pieczęciom następców Adama Sędziwoja, nie zaś jego przodków. Jego najbliższą analogię stanowią pieczęcie synów Adama: Władysława Sędziwoja Czarnkowskiego, starosty bydgoskiego w latach 1621-162422, oraz Franciszka Kazimierza Czarnkowskiego ${ }^{23}$. W polu owej pieczęci, podobnie jak na poprzednich, wyobrażono owalną tarczę herbową z Nałęczem Czarnkowskich, zwieńczoną hełmem z używanym przez tę rodzinę klejnotem. Inaczej niż na wcześniejszych pieczęciach, całość wyobrażenia mieści się $\mathrm{w}$ polu pieczęci. Jej legenda brzmi: + ADAM.SAND(ivoius).A. CZARNKOW. PAL(atinus): LAN(ciciensis). MA(ioris): POL(oniae): GEN(eneralis): WOL(minensis): CAP(itaneus).

Zaprezentowane wyżej zabytki nie stanowią pełnego zbioru pieczęci używanych przez Adama Sędziwoja Czarnkowskiego. Zauważono już brak sigillów sprzed 1593 r. Na inne braki wskazuje porównanie tego zespołu pieczęci z pieczęciami innych przedstawicieli rodziny. Dziś znamy trzy pieczęcie ojca Adama Sędziwoja - Wojciecha Sędziwoja Czarnkowskiego. Największa mierzyła $30 \mathrm{~mm}$ średnicy i ikonografią była zbliżona do najmniejszej pieczęci Adama ${ }^{24}$. Druga miała odmienny charakter: była to pieczęć sygnetowa, ośmioboczna o długości osi $17 \times 18 \mathrm{~mm}$. Wyobrażenie usytuowane w centrum jej pola wykazywało podobieństwo do wyżej omówionych herbów z tarczą jednopolową. Towarzyszyły mu sygle A(lbertus) S(andivoius)//A C(zarnkow) umieszczone w górnej części pola i rozdzielone przez klejnot ${ }^{25}$. Trzecia, również sygnetowa, owalna o wymiarach $17 \times 19 \mathrm{~mm}$, została przywieszona

22 Archiwum Państwowe w Bydgoszczy (dalej: AP w Bydgoszczy), Parafia św. Marcina i Mikołaja w Bydgoszczy 1346-1815, sygn. 1, k. 166; pieczęć Władysława jest niemal dwukrotnie większa, mierzy $42 \times 34 \mathrm{~mm}$; zob. też M. Hlebionek, Pieczęcie starostów bydgoskich w zasobie A[rchiwum] P [aństwowego w] B[ydgoszczy], Kronika Bydgoska, t. 28, 2006, katalog nr 9.

${ }^{23}$ Archiwum Archidiecezjalne w Gnieźnie (dalej: AArch w Gnieźnie), Zbiór listów (dalej: Zl), ta pieczęć jest zbliżona wymiarami do pieczęci Adama Sędziwoja: mierzy $29 \times 25 \mathrm{~mm}$.

${ }^{24}$ AP w Poznaniu, MK, sygn. 2404, odcisk z 1587 r.; Archiwum Państwowe w Gdańsku, Akta miasta Gdańska [1253, 1284] 1310-1815 [1944], sygn. 300, 53/27, k. 42; w polu pieczęci, oddzielonym od legendy ciągłą linią, znajduje się tarcza renesansowa z h. Nałęcz przełożonym; w klejnocie między rogami pióropusz z pawich piór, być może przeszyty strzałą (z lewej - heraldycznie - strony w połowie wysokości rogów jest widoczne zgrubienie, jakby końcówka strzały); pole wypełniają bogate labry; dół tarczy i góra pióropusza dzielą legendę. Legenda: S. ALB(erti) SAND(ivoii) A. CZARN(kow)// [...]CAP(itanei) [...] $\mathrm{PO}$ (loniae) $\mathrm{M}($ aioris $)$.

25 AP w Szczecinie, AKS, sygn. I/547, k. 198, odcisk z 1576 r. 
do aktu unii lubelskiej. Jej wyobrażenie nie odbiega od opisanych wcześniej przedstawień, choć wydawcy nie zauważają strzały przeszywającej pawi ogon znajdujący się w klejnocie. Wyobrażeniu towarzyszą sygle A(lbertus) S(adivoius) A C (zarnkow $)^{26}$. Rozpoznana spuścizna sfragistyczna po stryju Adama, Stanisławie Sędziwoju, referendarzu Zygmunta Augusta, składa się z dwóch pieczęci. Pierwsza to owalne sigillum o wymiarach $25 \times 20 \mathrm{~mm}$, które ukazuje Nałęcza Czarnkowskich z hełmem oraz klejnotem widocznym także na pieczęciach Adama Sędziwoja. W górnej części pola pieczęci znajdują się rozdzielone klejnotem heraldycznym sygle: S(tanislaus) S(andivoius)//A C(zarnkow) ${ }^{27}$. Pieczęć Stanisława Sędziwoja Czarnkowskiego (zapewne identyczną z wyżej opisaną), której odcisk pochodzi z 1570 r., Wiktor Wittyg przypisał Dobrogostowi Milińskiemu ${ }^{28}$. Drugie sigillum, również owalne, o wymiarach $16 \times 14 \mathrm{~mm}$, wyobraża uproszczony wizerunek herbu: w renesansowym kartuszu owalną tarczę z herbem Nałęcz w odmianie przełożonej. Nad kartuszem znajdują się sygle S S A C - należy je rozwiązywać podobnie jak w przypadku poprzedniej pieczęci Stanisława Sędziwoja ${ }^{29}$. Charakterystycznej pieczęci używał Jan Sędziwój Czarnkowski, starosta drahimski ${ }^{30}$. Mierzyła ona $31 \mathrm{~mm}$ średnicy, a jej specyfika polega na liternictwie legendy napieczętnej, w której zostały wymieszane litery majuskulne i minuskulne, na umieszczeniu inskrypcji wprost $\mathrm{w}$ polu pieczęci, a także na stylizacji wyobrażonego w nim herbu. Jej legenda brzmi: IOHANES SANDIUOGIUS A CZARNKOW CAP(itaneus) DRAH(imensis) ${ }^{31}$.

26 Akta unii Polski z Litwą 1385-1791, wyd. S. Kutrzeba, W. Semkowicz, Kraków 1932, s. 338, nr 137.

27 AP w Szczecinie, AKS, sygn. I/482, k. 27v (1581 r.); tamże, sygn. I/507, k. 23v (1583 r.); tamże, sygn. I/482, k. 53v (1587 r.).

28 W. Wittyg, Nieznana szlachta polska i jej herby, Kraków 1908, s. 204; odcisk ten powiązał z Czarnkowskim J. Szymański, Herbarz rycerstwa, s. 187, przyp. 4, choć za Wittygiem błędnie zidentyfikował dysponenta tej pieczęci jako M. S. Czarnkowskiego (u Wittyga - Masław Sędziwój Czarnkowski); niewątpliwie chodzi tu jednak o Stanisława Sędziwoja Czarnkowskiego, od 1567 r. referendarza świeckiego dworu królewskiego, zob. Urzędnicy centralni i nadworni Polski XIV-XVIII w. Spisy, oprac. K. Chłapowski, S. Ciara, Ł. Kądziela, T. Nowakowski, E. Opaliński, G. Rutkowska, T. Zielińska, red. A. Gąsiorowski, Kórnik 1992, s. 141, nr 895; s. 163.

29 AP w Szczecinie, AKS, sygn. I/507, k. 205v.

30 Tamże, sygn. I/603, k. 32 (1628 r.); sygn. I/555, k. 28; sygn. I/525, k. 180; AP w Szczecinie, Archiwum Książąt Wołogoskich [1401] 1532-1638 [1732], sygn. 407, k. 73 (1629 r.).

31 Pojawiające się w niej minuskulne litery to: „a”, „n” i „r”. 
Spośród przedstawicieli starszej linii Czarnkowskich najlepiej zbadane są pieczęcie Andrzeja, wojewody kaliskiego i starosty inowrocławskiego, syna Piotra, a wnuka Macieja Czarnkowskiego, kasztelana bydgoskiego i protoplasty tej gałęzi rodziny ${ }^{32}$. Znamy dziś szesśc należących do niego pieczęci. Odcisk najstarszej pochodzi z $1592 \mathrm{r} .{ }^{33}$ Jest to owalne, niewielkie $(20 / 22 \mathrm{~mm})$ sigillum wyobrażające $\mathrm{w}$ polu pieczęci renesansową tarczę $\mathrm{z}$ przełożoną pomłością, nad którą usytuowano en face zwieńczony koroną hełm z klejnotem: dwoma jelenimi rogami. $Z$ obu stron hełmu i tarczy rozmieszczono bogate labry. Wprost w polu pieczęci, na wysokości hełmu, znajdują się inicjały właściciela A/C. Odcisk kolejnej pieczęci Andrzeja pochodzi z 1602 r. ${ }^{34}$, choć powstała ona zapewne niedługo po jego nominacji na kasztelanię kaliską w 1599 r. ${ }^{35}$ Tym razem jest to okazate, okrągłe sigillum o średnicy $37 \mathrm{~mm}$. W polu tej pieczęci, oddzielonym od legendy ciągłą linią, wyobrażono tarczę herbową, której dół zachodzi na pole legendy, dzieląc umieszczoną tam inskrypcję. Tarcza składa się z czterech pól. W pierwszym znajduje się godło herbu Nałęcz w odmianie Czarnkowskich, w drugim i trzecim godło herbu Łodzia, w polu czwartym zaś godło herbu Poraj. Nad tarczą jest usytuowany hełm turniejowy; na jego szczycie umieszczono koronę z dwoma jelenimi rogami. Z obu stron hełmu są widoczne labry. Legenda pieczęci brzmi: ANDREAS CZARNKOWSKI CAST//ELL(anus) CALISIEN(sis) CAP(itaneus) IUNIWLAD(islaviensis). Z 1607 r. pochodzi kolejna pieczęć Czarnkowskiego o zbliżonych wymiarach (średnica $39 \mathrm{~mm}$ ) i ikonografii ${ }^{36}$. Od poprzedniej różni się ona tym, że tarcza herbowa nie zachodzi już na pole legendy. Jej powstanie należy wiązać z uzyskaniem przez Czarnkowskiego godności wojewody kaliskiego, co nastąpiło w 1605 r. Poświadcza to legenda na dwóch znanych odciskach tej pieczęci, zachowana co prawda szczątkowo, niemniej jednak pozwalająca na odczyt $\mathrm{w}$ formie: AND[.. C]ZARNKO[...] PALA(tinus) CALISS(iensis): CAP(itaneus): IVNIVLADISL(aviensis). Odcisk kolejnej „wojewodzińskiej” pieczęci Czarnkowskiego można odnaleźć w aktach klasztoru franciszkanów inowrocławskich ${ }^{37}$. Nie odbiega ona rozmiara-

32 W. Dworzaczek, dz. cyt., tabl. 106; Urzędnicy kujawscy i dobrzyńscy XVI i XVIII w. Spisy, oprac. K. Mikulski, W. Stanek, red. A. Gąsiorowski, Kórnik 1990, s. 108, nr 821; s. 223; Urzędnicy wielkopolscy, s. 53, nr 182; s. 82, nr 450.

${ }^{33}$ AP w Szczecinie, AKS, sygn. I/605.

34 Tamże, sygn. I/613, k. 30.

35 Urzędnicy wielkopolscy, s. 53, nr 182.

36 AP w Szczecinie, AKS, sygn. I/532; AP w Bydgoszczy, Klasztor Franciszkanów w Inowrocławiu [1258] 1623-1830 (dalej: KFI), sygn. 1.

37 AP w Bydgoszczy, KFI, sygn. 1. 
mi (średnica $39 \mathrm{~mm}$ ) i wyobrażeniem napieczętnym od poprzednio opisanych egzemplarzy większych sigillów starosty inowrocławskiego. Podobnie jak na pieczęci „kasztelańskiej”, tak i tu czteropolowa tarcza herbowa zachodzi na pole legendy. W lepiej zachowanej, niż na wyżej omówionych zabytkach, legendzie podkreślono godność wojewody kaliskiego: ANDREAS CZARNK[OWSKI] PALAT/IN(us) CALISIEN(sis) CAP(itaneus) IVNIWLADIS(laviensis). Równocześnie wojewoda Czarnkowski używał sygnetu, mniejszego od tego, który znamy z 1592 r. (wymiary $17 \times 14 \mathrm{~mm}$ ), o takiej samej jak poprzedni ikonografii ${ }^{38}$. Trudno precyzyjnie wydatować odcisk kolejnej pieczęci Andrzeja Czarnkowskiego, uwierzytelniającej wypis z ksiąg grodzkich inowrocławskich ${ }^{39}$. Nie ułatwia tego fragmentarycznie czytelna legenda: ANDR[...CZARNKOWSKI CASTEL]LAN(us)[...] ROGO[...]: CAP IUNIVL[...], która pozwala jedynie na konstatację, że pieczęć musiała powstać po 1598 r., kiedy to Czarnkowski został kasztelanem rogozińskim ${ }^{40}$. To sigillum, mimo że zbliżone rozmiarami (średnica $30 \mathrm{~mm}$ ), wyobrażeniem różni się jednak od wcześniej opisanych większych pieczęci Andrzeja. W jej polu umieszczono bowiem charakterystyczną, łezkowatą, renesansową tarczę z przełożonym Nałęczem, zwieńczoną ukoronowanym hełmem z jelenimi rogami w klejnocie. Biorąc pod uwagę ową prostotę przedstawienia, można się domyślać, że ta pieczęć mogła powstać, zanim nasz Andrzej otrzymał najwyższe godności: kasztelanię, a później województwo kaliskie. Nie można więc wykluczyć, że była ona używana w latach 1598-1600. Nieco inaczej wyglądają znane pieczęcie brata Andrzeja, Piotra Czarnkowskiego, właściciela Wronek i podkomorzego poznańskiego. Odcisk najstarszej z nich pochodzi z 1573 r., a zachował się przy liście, znajdującym się w archiwum archidiecezjalnym w Gnieźnie ${ }^{41}$. Jest to owalna $(20 \times 16 \mathrm{~mm})$ pieczęć, wyobrażająca w polu tarczę późnogotycką z nieco wydłużonym skrajem głowicy, z godłem herbu Nałęcz w odmianie używanej przez Czarnkowskich. Nad tarczą jest widoczny hełm prętowy na wprost, z renesansowymi labrami z obu stron. W klejnocie, umieszczonym nad szlachecką koroną, znajdują się rogi jelenie o pięciu odrostach. Klejnot rozdziela sygle: $\mathrm{P}($ etrus $) / \mathrm{C}($ arnkowski). Dwie kolejne pieczęcie Piotra zachowały się przy przywileju wydanym przez Czarnkowskiego dla mieszczanina wronieckiego ${ }^{42}$, który został uwierzytelniony

\footnotetext{
38 AP w Szczecinie, AKS, sygn. I/605, k. 16v.

39 AP w Bydgoszczy, KFI, sygn. 2.

40 Urzędnicy wielkopolscy, s. 155, nr 1092.

41 AArch w Gnieźnie, Zl, sygn. 290.

42 AP w Poznaniu, Akta miasta Wronki, sygn. 1.
} 
kontrasigillowanym odciskiem pieczęci. Pieczęć główna, wisząca przy tym dokumencie, jest owalna (mierzy 23/21 mm) i wyobraża w polu pieczęci renesansowo-barokową tarczę herbową z przełożoną pomłością, zwieńczoną hełmem z labrami po bokach. W klejnocie znajduje się pióropusz między dwoma jelenimi rogami. Klejnot rozdziela inskrypcję: $\mathrm{P}($ etrus $) \mathrm{C}($ zarnkowski)//[S(uccamerarius)] $\mathrm{P}$ (osnaniensis). Jako kontrasigillum użyto anepigraficznego owalnego sygnetu, o wymiarach $18 / 16 \mathrm{~mm}$, wyobrażającego w polu pieczęci tarczę z godłem herbu Nałęcz, nad którą jest usytuowany hełm z klejnotem i labrami. W klejnocie są widoczne dwa jelenie rogi z pióropuszem pośrodku. Wreszcie - z 1600 r. pochodzi odcisk niewielkiego sygnetu (wymiary 15/11 mm), wyobrażającego wprost w polu pieczęci przełożoną pomłość, której być może (podobnie jak w przypadku pieczęci Stanisława Sędziwoja Czarnkowskiego) towarzyszyły inicjały dysponenta.

Choć niepełne, zestawienie pieczęci wykorzystywanych przez najbliższych krewnych Adama Sędziwoja prowadzi do wniosku, że wśród opisanych wyżej sigillów tego możnego brakuje pieczęci sygnetowych, zazwyczaj owalnych (wyjątek stanowi ośmioboczna pieczęć Wojciecha Sędziwoja Czarnkowskiego), o wymiarach nieprzekraczających $25 / 22 \mathrm{~mm}$, prezentujących herb i, nierzadko, inicjały dysponenta. Wśród nich można wyróżnić dwa rodzaje: sygnety „większe” (jedna z ich osi przekraczała $20 \mathrm{~mm}$ ), częściej spotykane, z wyobrażeniem tarczy herbowej, hełmu z labrami i klejnotu, któremu towarzyszą sygle, mogące wskazywać również (jak w przypadku Piotra Czarnkowskiego) na godności dysponenta, oraz mniejsze, na których umieszczano jedynie tarczę z rodowym herbem w towarzystwie sygli bądź też pełny herb, ale pozbawiony inskrypcji. Pierwsze z nich spotykamy wśród pieczęci niemal wszystkich Czarnkowskich. Natomiast tych drugich dowodnie używali Stanisław Sędziwój z młodszej oraz Piotr Czarnkowski ze starszej linii rodu. Dlatego też, jak się wydaje, zbiór pieczęci Adama Sędziwoja należy uzupełnić o kategorię pieczęci sygnetowych, nie rozstrzygając jednak, czy wykorzystywał on sygnety „większe”, „mniejsze”, czy też, co jest bardzo prawdopodobne, oba ich rodzaje.

Ze względów formalnych (biorąc pod uwagę wielkość, kształt wyobrażenia i legendę) pieczęcie Adama Sędziwoja Czarnkowskiego można podzielić na cztery kategorie: większe, średnie, mniejsze, sygnetowe.

Średnica pieczęci większych wahała się od 40 do $45 \mathrm{~mm}$. Wyobrażały one skwadrowaną tarczę, nad którą znajdowały się dwa hełmy z klejnotami. Pieczęcie średnie nie różniły się od większych wielkością (średnica od 41 do $43 \mathrm{~mm}$ ), jednak uproszczono na nich wizerunek herbu: tarcza była jednopolowa, a wieńczył ją tylko jeden hełm z klejnotem. Z identycznym wizerun- 
kiem spotykamy się na pieczęciach mniejszych Adama Sędziwoja. Miały one inne wymiary od poprzednich, nieprzekraczające $30 \mathrm{~mm}$. Wśród nich można wyróżnić dwa rodzaje: okrągłe oraz owalne. Wreszcie - średnica pieczęci sygnetowych, których istnienie należy założyć, choć nie udało się dotąd odnaleźć żadnego ich egzemplarza, zapewne, analogicznie do pieczęci krewnych, sięgała około $20 \mathrm{~mm}$, wyobrażonemu na nich herbowi towarzyszyły zaś sygle wskazujące na osobę dysponenta bądź też nie miały one żadnej inskrypcji.

Inaczej będzie przedstawiała się struktura zespołu pieczęci Adama Sędziwoja, jeśli przeanalizujemy ją od strony prawno-funkcjonalnej. W tym przypadku wśród pieczęci Czarnkowskiego można wydzielić dwa zbiory: pieczęci urzędniczych oraz pieczęci prywatnych. Trzeba przy tym zaznaczyć, że granice między nimi były dość płynne i możemy znaleźć zarówno pisma urzędowe opatrzone sygnetem dysponenta ${ }^{43}$, jak i pisma prywatne wydane pod pieczęcią urzędniczą.

Zatrzymajmy się na chwilę przy zbiorze pieczęci urzędniczych. Zasadność używania tego określenia próbowałem wykazać w innym miejscu ${ }^{44}$. Propono-

${ }^{43} \mathrm{Na}$ przykład pisma Stanisława Sędziwoja Czarnkowskiego do książąt szczecińskich pieczętowane jego sygnetem czy też analogiczne pisma Andrzeja Czarnkowskiego. Pisma Stanisława: AP w Szczecinie, AKS, sygn. I/482, I/507, I/603; pisma Andrzeja zob. tamże, sygn. I/605.

${ }^{44}$ M. Hlebionek, Pieczęcie starostów, s. 322-326. Inne stanowisko reprezentują J. Łosowski, Pieczęcie starostów, s. 153-154, oraz M. Adamczewski, dz. cyt., s. 13, którzy ten typ pieczęci uznali za sigilla urzędowe (przyjmując dalszy ich podział na starościńskie i grodzkie). Użycie tego pojęcia zachowałbym jednak dla pieczęci, zawierających w legendzie nazwę instytucji, która posługiwała się nimi (depersonalizacja), w ikonografii zaś odwołujących się do znaków im właściwych (np. herbu państwowego w przypadku instytucji państwowych), co skutkuje znaczną unifikacją wyobrażeń, niezależnie od terytorium i okresu funkcjonowania pieczęci. Właściwe dla nich będzie również „długie trwanie", przekraczające zazwyczaj granice życia jednego pokolenia. W tym kontekście specyficzną hybrydą wynikającą z właściwości ustrojowych i społecznych terytorium byłyby znane z Prus Królewskich i Rusi, ale okresowo spotykane także na innych terenach, pieczęcie urzędów grodzkich, w inskrypcji zawierające jedynie nazwę urzędu (bez nazwiska starosty), w ikonografii zaś nawiązujące do herbu aktualnego starosty. Zob. Archiwum Archidiecezji Warmińskiej w Olsztynie (dalej: AArchW w Olsztynie), Akta biskupie (dalej: Ab), sygn. D-77, k. 66v, k. 97, k. 155: SIGILLVM' CASTREN(se):MAER[!] $B U R G E N(s e$ ?). W polu pieczęci otoczonym ciągłą linią renesansowa tarcza herbowa z godłem h. Jelita. Nad nią hełm (prętowy) z labrami. W klejnocie pół wspiętego kozła. Z obu stron klejnotu litery: L //D i poniżej D// Z. Dół tarczy dzieli pole legendy. Odciskom towarzyszą koroboracje wskazujące na charakter pieczęci: In quorum praedictorum fidem sigillum capitanealis officii castren(sis). Marienburgen(sis), praesentibus est subimpressum; In quorum rei fidem sigillum off(ic)y c(apitane)atus Marienburg(ensis) presentibus est appensum. O odmienności ustroju sądów grodzkich w Prusach Królewskich, 
wałem, by tym mianem określać pieczęcie prezentujące znak (zazwyczaj herb) dysponenta, w legendzie zaś wymieniające piastowane przezeń godności, służące przede wszystkim do uwierzytelniania pism będących efektem sprawowania określonego urzędu. Podobną sytuację opisał dla państw niemieckich Erich Kittel, który analogiczne do naszych pieczęcie, mające zarówno w ikono-, jak i logosferze charakter prywatny, używane jednak w sprawach urzędowych, określił jako private Beamtensiegel ${ }^{45}$.

Spośród pieczęci Adama Sędziwoja Czarnkowskiego do grupy pieczęci urzędniczych należały pieczęcie większe i średnie. Przy tym, jak można przypuszczać, pieczęcie większe łączyły się z piastowanym przez Czarnkowskiego urzędem starosty generalnego Wielkopolski. Zdaje się na to wskazywać fakt korzystania z nich w różnych miejscowościach, co świadczy o tym, że towarzyszyły one osobie starost ${ }^{46}$. Służyły one również do uwierzytelniania uroczystych ekstraktów z ksiąg grodzkich poznańskich ${ }^{47}$. Z działalnością urzędów grodzkich podległych staroście generalnemu należy jednak

będącej przyczyną pojawienia się tej kategorii pieczęci, zob. J. Bielecka, Organizacja i dziatalność sądów grodzkich w Prusach Królewskich w XV-XVIII wieku, Archeion, t. 65, 1977, s. 155-174. Dla Rusi zob. О. Алфьоров, О. Однорожєнко, Україські особові пєчаткі XV-XVII cm. за матєріаламі київских архівосховищ, Харків 2009, s. 24, nr 80 (odcisk z 1602 r.); leg. PIECZEC GROCKA GRODZIENSKA; w polu pieczęci oddzielonym od legendy ciągłą linią czteropolowy herb Andrzeja Wojny, nad nim hełm z pióropuszem ze strusich piór, w górnej części pola pieczęci sygle A//V rozdzielone pióropuszem; О. Однорожєнко, Рускі королівські, господарскі та князівскі пєчаткі XIII-XVI cm., Monumenta Rutheniae Heraldica, vol. 2, Харків 2009, s. 115-116; s. 265 , nr 348, 349, 350(?); wszystkie te pieczęcie miały jednobrzmiącą legendę, różniącą się nieco sposobem zapisu poszczególnych wyrazów: PIECZEC GRODSKA I VLODZIMIERSKA; wszystkie też wyobrażały otoczony syglami herb Wasyla Konstantego Ostrogskiego; tamże, s. 99, nr 243, 244; pieczęcie grodzkie krzemienieckie z czasów Krzysztofa Zbaraskiego: legendy różnią się jedynie kształtem dywizorów oraz skróceniem ostatniego wyrazu w drugiej z nich: PIECZENC GRODZKA POWIATV KRZEMIENIECKIEGO; obie też wyobrażają herb Zbaraskiego, w pierwszym przypadku uzupełniony o sygle: KZSK. Warto w tym miejscu zauważyć, że poprzednik Krzysztofa na urzędzie, Janusz Zbaraski, używał pieczęci z legendą brzmiącą: П€ЧAT КГРОД К ЯНУ 3 С КРЄ, oraz herbem. Byłaby to więc forma pośrednia, zawierająca w legendzie zarówno informacje o urzędzie, jak i osobie go piastującej. Na marginesie trzeba zaznaczyć, że owe pieczęcie zostały przez wydawców uznane za pieczęcie osobiste (prywatne). Cała ta grupa pieczęci pokazuje, jak płynna była w dawnej Rzeczypospolitej granica między sferą publiczną i prywatną.

45 E. Kittel, Siegel, Braunschweig 1970, s. 435.

46 Poznań - AP we Wrocławiu, KsO, rep. 33, sygn. 806, k. 149, k. 161, k. 231; Pyzdry - tamże, rep. 33, sygn. 806, k. 126.

47 AP w Poznaniu, AMP, sygn. D 494. 
wiązać chyba przede wszystkim grupę pieczęci średnich. W sferze ikonograficznej są one mniej reprezentacyjne od pieczęci większych, nie wyróżniają się też okazałością spośród pieczęci innych starostów grodzkich ${ }^{48}$. Niestety, podobnie jak w przypadku pieczęci większych, ich odciski znamy głównie z pism kierowanych do ościennych władców. Wyjątkiem są dwa egzemplarze uwierzytelniające ekstrakty z ksiąg grodzkich kaliskich ${ }^{49}$. Charakterystyczne jest to, że w polu tych ostatnich wizerunkowi herbu towarzyszą sygle „D/C”, które można odczytywać jako D(istrictus) C(alisiensis). Taka interpretacja tej inskrypcji świadczyłaby o związaniu typariusza z konkretnym urzędem grodzkim ${ }^{50}$. Przypomnijmy, że na mocy konstytucji z 1505 r. wszystkie pozwy wystawiane przez sąd grodzki miały być opatrzone pieczęcią starościńską ${ }^{51}$. Ponieważ urzędy grodzkie działały permanentnie, nawet pod nieobecność starosty, właściwe pieczęcie przez cały czas musiały pozostawać do ich dyspozycji. Pod nieobecność starosty jego pieczęcią starościńską opiekował się jeden z urzędników grodzkich ${ }^{52}$. W sytuacji, jaka wytworzyła się w Wielkopolsce, starosta generalny musiał zatem posiadać taką liczbę pieczęci urzędniczych, która umożliwiłaby płynne funkcjonowanie podległych mu instytucji. To stwierdzenie pozwala domyślać się istnienia pieczęci Adama Sędziwoja Czarnkowskiego przeznaczonych dla pozostałych grodów Wielkopolski znajdujących się pod zwierzchnictwem starosty generalnego (prócz Poznania i Kalisza były to: Kościan, Konin, Gniezno, Kcynia i Pyzdry). Dla naszych rozważań istotne jest spostrzeżenie Janiny Bieleckiej, datującej na przełom XVI i XVII w. reformę organizacji wielkopolskich sądów grodzkich. Dwa grody (Poznań i Kalisz), podległe dawniej staroście generalnemu, otrzymały tzw. prawo wieczności oraz, w związku z tym, nowego urzędnika - surogatora, który w zastępstwie starosty generalnego mógł przyjmować akta wieczyste oraz przewodniczył rokom skargowym. Jego kompetencje były jednak ogra-

48 J. Łosowski, Pieczęcie starostów, s. 156-165; tenże, Katalog pieczęci, s. 174-180; M. Hlebionek, Pieczęcie starostów, s. 328-330, 337-338.

49 ADiec we Włocławku, Zd, sygn. 1757, 1760.

50 To zjawisko zauważa M. Adamczewski, dz. cyt., s. 21.

51 Volumina Legum, t. 1, wyd. J. Ohryzko, Petersburg 1859, s. 137; J. Bielecka, Organizacja i dziatalność kancelarii ziemskich i grodzkich wielkopolskich wXIV-XVIII w., Archeion, t. 22, 1954, s. 142; taż, Kancelaria, s. 122.

52 Najczęściej był to susceptant lub specjalny urzędnik zwany „pieczętarzem”. Zob. J. Bielecka, Kancelaria, s. 133; J. Łosowski, Kancelaria grodzka chetmska od XV do XVIII w. Studium o urzędzie, dokumentacji, jej formach i roli $w$ życiu spoteczeństwa staropolskiego, Lublin 2004, s. 133. 
niczone do właściwego powiatu ${ }^{53}$. Pojawienie się osobnej pieczęci starościńskiej dla powiatu kaliskiego stanowi zapewne jeden ze śladów tych przemian. W okresie późniejszym elementy wskazujące na właściwość terytorialną pieczęci występują również na sigillach używanych przez inne grody, których zwierzchnikiem był starosta generalny, choć symptomatyczne jest to, że najwcześniej takich pieczęci używały właśnie Poznań i Kalisz ${ }^{54}$. Jest więc bardzo prawdopodobne, że w związku z reformą organizacji sądownictwa starościńskiego określenie terytorialne pojawiło się najpierw na pieczęciach grodów, w których działali surogatorzy, później zaś zostało wprowadzone na pieczęcie wykorzystywane przez pozostałe grody podległe staroście generalnemu ${ }^{55}$.

Rodzi się jeszcze pytanie o stosunek pieczęci większych do pieczęci średnich używanych przez gród poznański. Odpowiedź na nie znajdujemy w strukturze tej instytucji, w której - zdaniem J. Bieleckiej - funkcjonowa-

53 J. Bielecka, Organizacja, s. 141-143.

${ }_{44}$ M. Adamczewski notuje używanie przez Janusza Kościeleckiego pieczęci, w legendzie której tytułował się tylko starostą poznańskim. M. Adamczewski, dz. cyt., s. 21. Słabo czytelny zarys litery „D” lub „P” znajdujemy w prawej górnej (heraldycznie) kwarcie pola odcisku pieczęci średniej Czarnkowskiego użytej w Poznaniu w 1626 r. AP we Wrocławiu, $\mathrm{KsO}$, rep. 33, sygn. 806, k. 412. Tego samego typariusza użyto do uwierzytelnienia ekstraktu z ksiąg grodzkich poznańskich; zob. AP w Poznaniu, MK, sygn. 2385. Zarys litery „P” jest widoczny po lewej (heraldycznie) stronie tarczy herbowej na pieczęci użytej w 1620 r.; zob. AP w Szczecinie, AKS, sygn. I/537, k. 190. To zjawisko spotykamy również na późniejszych pieczęciach starostów generalnych Wielkopolski. Na pieczęci Jana Opalińskiego, z tytulaturą starościńską, w polu pieczęci, poniżej wyobrażenia, znajduje się inskrypcja: DISTRICT(us) POSNANIENSIS; zob. Archiwum Główne Akt Dawnych (dalej: AGAD), Archiwum Rodzinne Poniatowskich 1358-1797 (dalej: ARP), sygn. 15, k. 79. Na sigillum Jana Leszczyńskiego, z tytulaturą starościńską w legendzie, znajduje się inskrypcja: D(istri)CTVS POSN(aniensis). Zob. AP w Bydgoszczy, Klasztor Benedyktynów w Mogilnie [1169] 1520-1833 (dalej: KBM), sygn. 46, 47. Na pieczęci Rafała Leszczyńskiego w tym samym miejscu są czytelne litery PO[.]N. Zob. AP w Bydgoszczy, Archiwum Komierowskich z Komierowa 1647-1931 (dalej: AKK), sygn. 120, k. 163. Na pieczęciach Ludwika Szołdrskiego, w zależności od powiatu, dla którego pieczęć była używana, z obu stron klejnotu herbowego znajdują się inskrypcje: [D]ISTR(ictus)//POSNAN(ensis), AP w Bydgoszczy, KBM, sygn. 84; DISTR(ictus)// KCYN(ensis), AP w Bydgoszczy, AKK, sygn. 80, k. 304, 305, 307; DISTR(ictus)//PISDR(ensis), tamże, sygn. 60 [niepaginowana]; DISTR(ictus)// GNESN(ensis), tamże.

${ }^{55} \mathrm{Na}$ pieczęci starosty generalnego Andrzeja Opalińskiego, bezpośredniego poprzednika Adama Sędziwoja na urzędzie starosty, sygle wskazujące na powiat, z którym pieczęć była związana, jeszcze się nie pojawiają. Może to jednak wynikać z tego, że była to pieczęć dla któregoś z powiatów niemających surogatora. Zob. AArchW w Olsztynie, Ab, sygn. D-75, k. 79v. 
ły trzy komórki wytwarzające akta: sąd starosty, sąd urzędu oraz sam urząd-kancelaria ${ }^{56}$. Pieczęć większą należy chyba wiązać przede wszystkim z osobą starosty i sądem starościńskim, podczas gdy pieczęć średnia obsługiwałaby działalność sądu urzędu i kancelarii grodzkiej, pozostając w dyspozycji surogatora.

Pozostałe pieczęcie Adama Sędziwoja Czarnkowskiego - mniejsze i sygnetowe - były zapewne jego pieczęciami prywatnymi. W tym miejscu znów należy podkreślić umowność takiego podziału. Najlepiej świadczy o tym fakt, że pieczęcią mniejszą okrągłą opatrzono zarówno prywatny skrypt dłużny Czarnkowskiego dla miasta Poznania, jak i jeden z jego listów do książąt pomorskich, w którym występował jako starosta generalny ${ }^{57}$. Podobnie, jak już wyżej wspomniano, sygnetami były opatrywane listy Stanisława Sędziwoja czy Andrzeja Czarnkowskich do książąt szczecińskich. Użycie pieczęci tej kategorii zależało zatem wyłącznie od woli dysponenta, a jej walor prawny wiązał się z jego autorytetem ${ }^{58}$. Znane pieczęcie prywatne Czarnkowskiego nie różniły się kształtem ani wymiarami od pieczęci osób o zbliżonym statusie społecznym ${ }^{59}$.

Dysponując tymi danymi, możemy pokusić się o rekonstrukcję systemu sfragistycznego ${ }^{60}$ Adama Sędziwoja Czarnkowskiego. Tworzyły go dwa pod-

56 J. Bielecka, Inwentarze ksiąg archiwów grodzkich i ziemskich Wielkopolski XIV-XVIII wieku, Poznań 1965, s. 32.

57 AP w Poznaniu, AMP, sygn. D 151; AP w Szczecinie, AKS, sygn. I/535, k. 11v.

$58 \mathrm{Na}$ ten związek, występujący już w średniowieczu, zwraca uwagę M. Günther, Das Siegelrecht des Mittelalters erläutert aus dem sphragistischen Formeln, welche des eigen Siegels Abwesenheit oder Mangel, die s[o] g[ennante] Siegel Carenz beziechnen, Leipzig 1870 , s. VI.

59 W. Strzyżewski, dz. cyt., s. 64-70.

60 Przez system sfragistyczny będziemy niżej rozumieć zbiór pieczęci należących do osoby fizycznej bądź prawnej, połączonych wzajemnymi relacjami wynikającymi z chronologii użytkowania, praktyki kancelaryjnej oraz pozycji społecznej i kompetencji prawnych dysponenta. Obrazuje je wyobrażenie napieczętne (z reguły zróżnicowane treściowo w zależności od właściwości prawnych dysponenta), legenda i inskrypcje (które towarzysząc przedstawieniu, werbalnie identyfikowały dysponenta pieczęci, informując o charakterze i zakresie jego władzy), a także wielkość (wskazująca często na miejsce pieczęci w hierarchii) i, niekiedy, kształt pieczęci. Zob. też A. Baniecki, D. Bednarek, D. Żygadło, R. Forysiak-Wójciński, P. Gut, J. Leśniewska, M. Hlebionek, Materiaty do polskiego stownika sfragistycznego, Archiwista Polski, nr 3, 2010, s. 54; zob. definicję systemu sfragistycznego podaną przez Z. Piecha, który rozumie go jako „wzajemnie skorelowany układ odpowiadający ustrojowi, strukturze i hierarchii kompetencji [instytucji]. Jego zewnętrznym wyrazem było wyobrażenie napieczętne z reguły zróżnicowane treściowo w zależności od kompetencji urzędów oraz legenda, która towarzyszyła przedsta- 
systemy: pieczęci urzędniczych oraz pieczęci osobistych. W skład pierwszego wchodziły pieczęć większa Czarnkowskiego, odpowiadająca godności starosty generalnego, oraz pieczęcie średnie pozostające $\mathrm{w}$ dyspozycji grodów podległych staroście generalnemu, ewentualnie związane z funkcjonowaniem innych piastowanych przezeń urzędów. Ze względów chronologicznych ten system można podzielić dalej na dwa zbiory: pieczęci używanych do $1606 \mathrm{r}$. oraz po tej dacie. Cezurą jest tu rok aktualizacji garnituru pieczęci na skutek otrzymania godności wojewody łęczyckiego. Drugi podsystem obejmuje pieczęcie prywatne Czarnkowskiego, wśród których można wyodrębnić zbiór pieczęci „mniejszych” oraz sygnetowych.

\section{SYSTEM INFORMACYJNY PIECZĘCI Adama Sędziwoja Czarnkowskiego}

Przez system informacyjny pieczęci należy rozumieć charakterystyczny i łatwy do porównania, a przez to weryfikacji, zbiór cech pieczęci, powiązanych ze sobą, umożliwiających identyfikację dysponenta pieczęci oraz wskazujących na jej miejsce $\mathrm{w}$ systemie sfragistycznym właściciela. W wyniku ewolucji pieczęci ustaliły się schematy, nie tylko określające, jakie elementy systemu, ale też $\mathrm{w}$ jakiej formie powinny znajdować się na danym typie pieczęci, należącym do poszczególnej kategorii dysponentów ${ }^{61}$.

W skład zbioru elementów tworzących system informacyjny pieczęci wchodzą: wyobrażenie napieczętne, legenda, czy szerzej - inskrypcje znajdujące się na pieczęci, oraz kształt i wymiary pieczęci. Związki łączące wymienione komponenty można podzielić na dwie grupy: merytoryczne i formalne, przy czym relacje formalne często są pochodną relacji merytorycznych. Relacje merytoryczne wynikają z roli, jaką poszczególne elementy systemu odgrywają w procesie komunikacji. Niech za przykład posłużą związki między wyobrażeniem napieczętnym i legendą. Będą to niewątpliwie relacje hierar-

wieniu i werbalnie identyfikowała dysponenta pieczęci, informując o charakterze i zakresie jego władzy". Z. Piech, Średniowieczne pieczęcie tynieckie, [w:] Benedyktyni tynieccy w średniowieczu, red. K. Żurowska, Tyniec-Kraków 1995, s. 123.

${ }^{61}$ Świadczy o tym konflikt o pieczęć pokojową, której ikonografia mogła doprowadzić do mylenia jej z pieczęcią mniejszą koronną. W. Krawczuk, Pieczęcie Zygmunta III Wazy, Kraków 1990, s. 7 i n.; M. Hlebionek, Nowożytne pieczęcie królów polskich, [w:] Polska kancelaria królewska czasów nowożytnych między wtadzq a spoteczeństwem. Materiaty konferencji naukowej, Torun, 18 kwietnia 2002 roku, red. W. Chorążyczewski, W. Krawczuk, Toruń 2003, s. 57. 
chiczne, choć znaczenie tych dwóch elementów, a co za tym idzie - ich miejsce w hierarchii informacyjnej, na przestrzeni dziejów ulegało zmianie. Graficznym wyrazem tej hierarchizacji są łączące oba elementy relacje formalne, tj. położenie wyobrażeń i napisów względem siebie, proporcje ich wielkości itp. Te czynniki mają wpływ na kolejność odbioru komunikatów, przebiegającą zwykle od największego ku mniejszym elementom. Oczywiście, hierarchizacja to niejedyna relacja między legendą i wyobrażeniem. Jak się wydaje, ważniejsze są dwa inne rodzaje związków: po pierwsze - oba elementy wzajemnie się uzupełniają, po drugie - wyjaśniają ${ }^{62}$. Dalej należy wskazać na relacje łączące elementy informacyjne poszczególnych typów pieczęci, wchodzących w skład jednego systemu sfragistycznego. Rozbudowa lub redukcja wyobrażenia i legendy o kolejne elementy znaczące mogła służyć rozróżnianiu pieczęci funkcjonujących równocześnie i stanowiących komponenty jednego systemu. Mielibyśmy tu zatem do czynienia z relacją tożsamości bądź nietożsamości poszczególnych elementów informacyjnych.

Pieczęcie Adama Sędziwoja Czarnkowskiego pod względem wielkości i kształtu zostały scharakteryzowane już wyżej. Pieczęcie urzędnicze magnata mierzyły od 40 do $45 \mathrm{~mm}$. Stawia je to w jednym rzędzie z mniejszymi i pokojowymi pieczęciami królewskimi ${ }^{63}$. Wyróżniały się one wielkością spośród pieczęci innych współczesnych starostów prowincji wielkopolskiej. Działający na przełomie XVI i XVII w. starostowie bydgoscy używali pieczęci o średnicy około $30 \mathrm{~mm}$ (Janusz Kościelecki, okrągła, 28 mm; Maciej Smogulecki, owalna, 32/27 mm ${ }^{64}$. Wzrost ich wielkości widać w czasach Władysława Sędziwoja Czarnkowskiego, którego owalna, urzędnicza pieczęć mierzyła 42/34 mm. Na przełomie XVI i XVII w., a więc wtedy, gdy Adam Sędziwój sprawował godność starosty generalnego, starostą inowrocławskim był Andrzej Czarnkowski. Jego pieczęcie scharakteryzowano wyżej. Przypomnijmy jednak ich wymiary. Najstarsza z nich, pochodząca z 1597 r. pieczęć z tytulaturą wyłącznie starościńską (starosta inowrocławski i rogoziński), była okrągła i mierzyła $30 \mathrm{~mm}$ średnicy. Kolejna pieczęć Czarnkowskiego, którą sprawił sobie po otrzymaniu kasztelanii kaliskiej, również okrągła, mierzyła $37 \mathrm{~mm}$ średnicy, wreszcie - pieczęć starosty inowrocławskiego i wojewody kaliskiego miała średnicę $39 \mathrm{~mm}$. Można tu zauważyć wzrost rozmiarów pieczęci równoległy do obejmowania coraz to bardziej prestiżowych urzędów.

62 S. K. Kuczyński, Polskie herby ziemskie. Geneza. Treści. Funkcje, Warszawa 1993, s. $125-127$.

63 W. Krawczuk, dz. cyt., s. 17-23.

${ }^{64}$ M. Hlebionek, Pieczęcie starostów, s. 331, s. 337-338, nr 6-9. 
Przypuszczalnie podobnie było w przypadku Jana Opalińskiego, następcy Andrzeja Czarnkowskiego na starostwie inowrocławskim, a także kasztelanii kaliskiej i później województwie kaliskim. Jego pieczęć pochodząca z 1632 r., a więc z czasów, kiedy osiągnąwszy szczyt kariery, piastował już godność wojewody kaliskiego, jest okrą̧ła i mierzy $43 \mathrm{~mm}$ średnicy. Znacznie mniejsze były za to pieczęcie używane w pierwszej połowie XVII w. przez starostów kruszwickich. Maciej Grabski posiadał sigillum o średnicy $29 \mathrm{~mm}$, pieczęć Jerzego Kucińskiego mierzyła 26/21 mm, zachowany zaś odcisk owalnej pieczęci Konstantego Lubstowskiego mierzy 29/34 mm ${ }^{65}$. Pozostając jeszcze w kręgu starostów prowincji wielkopolskiej, warto zauważyć, że starosta wałecki z przełomu XVI i XVII w. Jan Gostomski posiadał pieczęć o średnicy $32 \mathrm{~mm}^{66}$, a piastujący tę samą godność w połowie XVIII w. Władysław Kąsinowski używał typariusza o średnicy $50 \mathrm{~mm}^{67}$. Na tym tle pieczęcie urzędnicze Adama Sędziwoja Czarnkowskiego prezentują się najokazalej. Spośród innych przywołanych wyżej przykładów są one porównywalne tylko z pieczęciami starostów, sprawujących jednocześnie urzędy wojewodzińskie. Zapewne zachodzi tu zjawisko analogiczne do tego, które opisał J. Łosowski, porównując rozmiary pieczęci starostów chełmskich i krakowskich: wyższa ranga urzędu starosty generalnego Wielkopolski znajdowała odbicie w wielkości jego pieczęci ${ }^{68}$.

W materiale sfragistycznym widać też tendencję do stopniowego zwiększania średnicy pieczęci starostów generalnych. Pieczęcie Adama Sędziwoja, jak już wspomniano, oscylowały między 40 a $45 \mathrm{~mm}$, choć znana pieczęć jego poprzednika na starostwie generalnym mierzyła $35 \mathrm{~mm}^{69}$. Nieco więk-

${ }^{65}$ Odciski wszystkich pieczęci: AP w Bydgoszczy, Klasztor Norbertanek w Strzelnie 1193-1836 (dalej: KNS), sygn. 162.

${ }^{66}$ AP w Szczecinie, AKS, sygn. I/525, k. 180. Legenda słabo czytelna brzmi: *IOAN[...]WALC. W polu pieczęci, oddzielonym od legendy ciągłą linią, tarcza z h. Nałęcz, hełmem, labrami, w klejnocie panna między rogami jelenia.

${ }^{67}$ AGAD, ARP, sygn. 43, k. 5. Legenda: VLADISLAVS CONSTANTINVS IN KASINOWO KASINOWSKI CAPITANEVS WALCENSIS A. 1745. W polu pieczęci, oddzielonym od legendy ciągłą linią, kartusz z h. Nałęcz, w odmianie przełożonej. Nad nim korona szlachecka. Kartusz został ujęty od dołu w dwie gałązki palmowe.

${ }^{68} \mathrm{Z}$ zestawienia wielkości pieczęci, dokonanego przez J. Łosowskiego, wynika, że średnica pieczęci starostów chełmskich generalnie mieściła się w przedziale $30-39 \mathrm{~mm}$. Inaczej wyglądała sytuacja w grodzie krakowskim. W XVI i jeszcze w początkach XVII w. średnica pieczęci sięgała $30 \mathrm{~mm}$, podczas gdy w ciągu XVII w. nastąpił gwałtowny skok wielkości: ich wymiary przekroczyły 40 , a nawet $50 \mathrm{~mm}$. J. Łosowski, Pieczęcie starostów, s. 166-167.

${ }^{69}$ Zob. AArchW w Olsztynie, Ab, sygn. D-75, k. 79v. 
sze były pieczęcie Bogusława Leszczyńskiego z połowy XVII w., mierzące od 45 do $48 \mathrm{~mm}^{70}$. Pieczęcie dalszych Leszczyńskich mierzyły odpowiednio: Rafała (owalna) $53 / 48 \mathrm{~mm}$, a Jana (okrągła) $45 \mathrm{~mm}^{71}$. Pochodzący z początków XVIII w. odcisk owalnego sigillum Macieja Radomickiego, przeznaczonego dla powiatu poznańskiego, mierzy $40 / 60 \mathrm{~mm}^{72}$. Owalne pieczęcie Szołdrskich z połowy następnego stulecia mierzyły 60/50 mm (Ludwika) i 65/55 mm (Władysława) ${ }^{73}$, podobne w kształcie pieczęcie Jerzego Augusta Wandalina Mniszcha $62 / 55 \mathrm{~mm}^{74}$, a okragłe sigilla Kazimierza Raczyńskiego około $60 \mathrm{~mm}^{75}$. Ów stały wzrost rozmiarów pieczęci starostów J. Łosowski tłumaczy „wzbogacaniem funkcji pieczęci, dzięki czemu w większym stopniu pełniła [ona] rolę środka komunikacji między jej dysponentem a odbiorcą"76. Rzeczywiście, zwiększaniu rozmiarów sprzyjała rozbudowa elementów wchodzących w skład systemu informacyjnego pieczęci. Jednak, jak się wydaje, nie była to przyczyna, a raczej jeden ze skutków innego zjawiska: dążenia do eksponowania własnej pozycji społecznej. Jak zauważył Andrzej Wyrobisz w odniesieniu do magnackich fundacji architektonicznych:

dzieła architektoniczne miały mówić same za siebie, a raczej za swoich fundatorów, winny przemawiać samą swoją substancją. Powinny być ostentacyjnie wspaniałe i kosztowne, ozdobne i piękne, aby skutecznie głosić chwałę tych, co je fundowali, i umacniać ich pozycję społeczną. Powinny przyciągać uwagę niecodziennością programu użytkowego lub wręcz ekstrawagancją, rzucać się w oczy wielkością i monumentalną skalą, często przekraczającą rzeczywiste potrzeby ${ }^{77}$.

To stwierdzenie można odnieść również do pieczęci urzędniczych, które, jako że funkcjonowały w przestrzeni publicznej, najlepiej nadawały się do eksponowania pozycji społecznej dysponenta. Temu właśnie służyło zwięk-

70 AP w Bydgoszczy, Rejencja w Bydgoszczy 1815-1919, i tam Domänen Amt Skórzęcin [bez sygnatury]; Urzędnicy wielkopolscy, s. 165, nr 1189.

${ }^{71}$ Rafał Leszczyński: AP w Bydgoszczy, AKK, sygn. 120, k. 163; Jan Leszczyński: AP w Bydgoszczy, KBM, sygn. 46, 47.

${ }^{72}$ AGAD, ARP, sygn. 43, k. 68.

${ }^{73}$ AP w Poznaniu, Zbiór tłoków pieczęci, sygn. T III 12 (pieczęć dla powiatu kościańskiego).

${ }^{74}$ AP w Bydgoszczy, AKK, sygn. 80, k. 314.

75 AP w Poznaniu, Zbiór tłoków pieczęci, sygn. T III 6.

76 J. Łosowski, Pieczęcie starostów, s. 167.

77 A. Wyrobisz, Architektura w stużbie spotecznej i politycznej w Polsce XVI-XVIII wieku, [w:] Podtug nieba i zwyczaju polskiego. Studia z historii architektury, sztuki i kultury ofiarowane Adamowi Mitobędzkiemu, red. Z. Bania, Warszawa 1988, s. 525. 
szanie ich rozmiarów, rozbudowa ikonografii, uzupełnianie głównie herbowych wizerunków o panoplia oraz insygnia urzędnicze czy też rozwijanie umieszczanej w legendzie tytulatury, co skutkowało wzrostem ilości informacji przekazywanych za pomocą stempla.

Pieczęcie osobiste szlachty nie były tak zróżnicowane pod względem wielkości. Analiza tego typu materiału sfragistycznego, przeprowadzona dla szlachty księstwa głogowskiego, wykazała, że niezależnie od okresu funkcjonowania miały one, w ramach określonej warstwy stanu szlacheckiego, zbliżone wymiary (wahające się zasadniczo od 15 do około $30 \mathrm{~mm}$, w zależności od pozycji społecznej dysponenta, choć pieczęcie szlachty tytularnej osiągały wymiary przekraczające $40 \mathrm{~mm})^{78}$.

Znamy odciski dwóch pieczęci prywatnych Adama Sędziwoja. Pierwsza z nich, okrągła, miała średnicę $24 \mathrm{~mm}$, druga zaś, owalna, osie o wymiarach 28/23 mm. Oba sigilla Adama Sędziwoja różniły się znacznie wielkością od pieczęci urzędniczych możnowładcy, ale nie wykraczały poza standardowe rozmiary pieczęci szlacheckich z terytorium księstwa głogowskiego ${ }^{79}$. Pieczęci prywatnych o zbliżonych rozmiarach, choć innej formie, używali równocześnie krewni Adama Sędziwoja.

Pieczęcie urzędnicze, wykorzystywane przez starostów, były z reguły okrągłe. Tak też jest w przypadku wszystkich pieczęci tego rodzaju należących do Adama Czarnkowskiego. Jednak już w końcu XVI w. coraz większą popularność zyskały pieczęcie owalne, których w ciągu XVII i XVIII w. używano wymiennie z pieczęciami okrągłymi. Niewiele większa jest różnorodność kształtów wśród pieczęci osobistych. Jak już wspomniano, znane pieczęcie prywatne Adama Sędziwoja miały kształt okrągły i owalny. Owalna była też większość osobistych pieczęci jego współrodowców. Wyjątkiem jest tutaj sygnetowe, ośmioboczne sigillum Wojciecha Sędziwoja Czarnkowskiego. Wydaje się, że okrągła pieczęć Adama Sędziwoja może stanowić wyraz pewnego tradycjonalizmu - zarówno kształtem, jak i układem poszczególnych elementów umieszczonych na stemplu nawiązuje bowiem do schematów wypracowanych jeszcze w średniowieczu. Inaczej jest z pieczęcią owalną. Sigilla o takim kształcie W. Strzyżewski uznał za charakterystyczne dla epoki wczesnonowożytnej, choć funkcjonowały one również w następnych stuleciach ${ }^{80}$.

Strukturę semantyczną, która znajdowała się na stemplu, tworzyły zazwyczaj dwa różne kody: ikoniczny (wyobrażenie) i umowny (symboliczny,

\footnotetext{
78 W. Strzyżewski, dz. cyt., s. 66-70.

79 Tamże, s. 67-69.

80 Tamże, s. 65.
} 
czyli tekst). Przekaz zawarty na pieczęci miał więc charakter synkretyczny. Niewątpliwie oba środki wyrazu były skorelowane. W przypadku szlacheckich pieczęci herbowych ${ }^{81}$ te rodzaje przekazu uzupełniały się, ale też dublowały. Zarówno bowiem sam herb, jak i towarzysząca mu zwykle (choć przecież nie zawsze) inskrypcja niezależnie od siebie wskazywały na osobę dysponenta pieczęci. Wszak na pieczęciach anepigraficznych funkcję identyfikacyjną pełniła jedynie kompozycja heraldyczna. Do pomyślenia byłyby również pieczęcie operujące jedynie tekstem, który także określałby właściciela typariusza. Owo zdublowanie informacji przekazywanych przez obie składowe tej struktury semantycznej wynikało z właściwości obu środków przekazu. Jak zauważył Ernst Gombrich, „poprawne odczytanie znaku wizualnego zależy od trzech zmiennych: kodu, podpisu i kontekstu" ${ }^{82}$. Sam herb, w polskich warunkach, wskazywał przede wszystkim na stan społeczny dysponenta oraz rodzinę, z której on pochodzit ${ }^{83}$. Widoczne są jednak działania mające na celu personalizację tego znaku. Miało temu służyć stosowanie herbów złożonych, które, przez określenie genealogii dysponenta, ujednoznaczniały wizerunek. Podobną funkcję pełniło też wprowadzenie do ikonografii pieczęci insygniów i atrybutów urzędniczych. Tekst, mający, w odróżnieniu od obrazu, charakter bardziej jednoznaczny, jeżeli wykorzystywał kod znany potencjalnemu odbiorcy komunikatu (tzn. w czytelnym dla odbiorcy języku oraz znanym odbiorcy pismem), wskazywał bezpośrednio na osobę dysponenta. Niemniej jednak zarówno napisy (podanie imienia i nazwiska dysponenta), jak i herb (elementy znaczące - godło, klejnot) przekazywały informacje służące jego identyfikacji. Oprócz tego, odnosząc się do przywołanego wyżej cytatu z Gombricha, znajdujące się na pieczęci inskrypcje podpisywały wizerunek, sugerując jednocześnie kontekst jego użycia ${ }^{84}$. Wspomniano już, że oba elementy przekazu łączyły relacje hierarchiczne. Wiążą się one z za-

81 Inaczej sytuacja wyglądała w przypadku np. pieczęci herbowych królewskich, w których inskrypcja wskazywała na władcę jako nominalnego dysponenta pieczęci, umieszczone na pieczęci herby odnosiły się natomiast do terytoriów wchodzących w skład władztwa. Szerzej zob. M. Hlebionek, System heraldyczny pieczęci królów polskich, [w:] Pieczęcie herbowe - herby na pieczęciach. II Krakowskie Kolokwium Heraldyczne, red. Z. Piech, W. Drelicharz, Warszawa 2011, s. 29-30.

82 E. Gombrich, Obraz wizualny, [w:] Symbole i symbolika, oprac. M. Głowiński, Warszawa 1990, s. 319.

83 Stąd też W. Strzyżewski dla szlachty księstwa głogowskiego wyodrębnił kategorie pieczęci rodzinnych. Tenże, dz. cyt., s. 56-57, 61-64.

84 A. Seidel-Grzesińska, M. Wisłocki, Stowo a obraz. O roli inskrypcji w konstytuowaniu dzieta sztuki, Studia Epigraficzne, t. 1, 2004, s. 104, 111. 
proponowanymi przez Mieczysława Wallisa pojęciami pola semantycznego i enklawy semantycznej ${ }^{85}$. Pole semantyczne to według Wallisa „układ przestrzenny lub czasowy, lub jeszcze jakiś inny, w którym pewien znak przybiera różne znaczenie $\mathrm{w}$ zależności od miejsca, jakie on lub jego elementy znajdują w układzie”. Enklawa semantyczna z kolei „to część pewnego dzieła sztuki składająca się ze znaków innego rodzaju niż znaki tworzące dzieło sztuki"86. W kontekście rozważań nad pieczęciami rodzi się pytanie, który z elementów struktury semantycznej odgrywał rolę prymarną, czyli był polem semantycznym, który zaś był jedynie enklawą. Sytuacja ulegała bowiem zmianie na przestrzeni dziejów, z jednej strony - wraz ze wzrostem piśmienności społeczeństwa, z drugiej zaś - wraz z kostnieniem heraldyki, powodującym ograniczenie jej możliwości komunikacyjnych. Analiza wzajemnego układu ikono- i logosfery pieczęci (relacji stylistyczno-kompozycyjnych), a także ich proporcji (stosunku ilościowego) wskazuje na kolejność odbioru obu komunikatów oraz hierarchię obu sposobów kodowania informacji.

$\mathrm{Na}$ znanych pieczęciach Adama Sędziwoja Czarnkowskiego spotykamy się z trzema układami obu elementów semantycznych. W pierwszym, charakterystycznym dla pieczęci większych i okrągłej mniejszej, herb jest umieszczony na pionowej osi pieczęci, dzieląc na dwie części biegnącą skrajem pieczęci inskrypcję, której pole zostało wyraźnie wydzielone. W tej odmianie nad znakiem znajduje się data, wykonana pismem o module mniejszym od tego występującego w inskrypcji otokowej i niełącząca się merytorycznie z legendą, wskazująca jednak na czas sporządzenia typariusza. Drugi układ znaków najczęściej pojawia się na pieczęciach średnich. W tym przypadku, tak jak na pieczęciach większych, znak dysponenta jest umieszczony na pionowej osi odcisku, z tym że biegnącą skrajem inskrypcję dzieli on tylko u dołu. Jego odmianę spotykamy na pieczęciach grodu kaliskiego, gdzie prócz legendy, u dołu podzielonej tarczą heraldyczną, z obu jej stron występują sygle wskazujące na urząd grodzki dysponujący typariuszem. Trzeci układ został zastosowany na pieczęci mniejszej owalnej Adama Sędziwoja. Herb jest tam usytuowany w centrum pieczęci, wzdłuż dłuższej jej osi, legenda zaś obiega nieprzerwanie jej skraj. Na podstawie zachowanych odcisków innych przedstawicieli rodziny Czarnkowskich możemy domyślać się rozwiązań, które

85 M. Wallis, Sztuka średniowieczna jako język. Próba zastosowania pojęć semiologicznych do historii sztuki, [w:] M. Wallis, Wybór pism estetycznych, Kraków 2004, s. 276. W kontekście nauk pomocniczych historii pojęcia te prezentuje Z. Piech, Znak jako przedmiot badań historycznych, [w:] Pamiętnik XV Zjazdu Historyków Polskich, t. 1, z. 2, red. J. Staszewski, s. 253-254.

86 M. Wallis, dz. cyt., s. 276. 
mogły być stosowane na hipotetycznych sygnetowych pieczęciach Adama. Spotykamy tam trzy różne układy ikono- i logosfery. W pierwszym herb został wyobrażony w centrum pieczęci, wzdłuż jej pionowej (w przypadku pieczęci owalnych - dłuższej) osi, inskrypcja zaś została umieszczona prostopadle do herbu, w górnej części pola pieczęci, i podzielona przez wizerunek na dwie części. Zbliżone do tego układu jest kolejne rozwiązanie stosowane na pieczęciach sygnetowych - wyobrażenie znajduje się poniżej inskrypcji tak, że nie dzieli jej. Trzeci wreszcie typ ogranicza się do ukazania wyłącznie herbu dysponenta, pozbawionego jakichkolwiek napisów.

Stosunek ilościowy pomiędzy wyobrażeniem napieczętnym a tekstem można określić przez wskazanie na proporcje pomiędzy średnicą pola pieczęci, na którym umieszczono wyobrażenie, a wysokością pola inskrypcji, która miała wpływ na moduł użytego pisma. W przypadku pieczęci Adama Sędziwoja ten stosunek miał się jak 1 do $10 \mathrm{w}$ przypadku pieczęci urzędniczych oraz 1 do 7 i 1 do 5 w przypadku pieczęci mniejszych. Należy jednak podkreślić, że mimo oczywistej dominacji pola pieczęci zastosowane przy kompozycji sigillum proporcje wielkości wyobrażenia i napisu zapewniały inskrypcjom dostateczną czytelność (jeśli typariusz został dobrze odciśnięty).

Wydaje się więc, że paradoksalnie, z dzisiejszego punktu widzenia, bogatsza w informacje inskrypcja zajmowała niższe miejsce w hierarchii. Świadczy o tym umieszczanie wizerunku w centrum pieczęci, a więc miejscu bardziej eksponowanym, oraz fakt, że to właśnie sposób ekspozycji wyobrażenia determinował układ inskrypcji. Nie bez znaczenia są również proporcje ilościowe, zdające się jednoznacznie wskazywać na dominację obrazu nad tekstem. Trzeba tu zauważyć, że choć, w tym przypadku, czynnikiem nadrzędnym była czytelność napisu, to jego wielkość starano się ograniczyć do rozmiarów minimalnych, zapewniających ową czytelność ${ }^{87}$. Przewaga kodu ikonicznego, oprócz czynników kulturowych, wynikała z różnic w percepcji obrazu i tekstu. Obraz pozwala na szybki odbiór komunikatu, a odbiorca sam ustala reguły jego odczytywania, przesuwając wzrok od jednego znaku do drugiego. Odczytanie napisu wymaga większego wysiłku, rządzą nim bowiem określone reguły. Śledzenie linii tekstu umieszczonego wzdłuż krawędzi pieczęci jest tym bardziej trudne, że przybiera ona „nienaturalny” kształt i często wymaga manipulacji odciskiem.

87 M. Hlebionek, Pieczęcie starostów, s. 327-328. Metoda badania proporcji znajduje lepsze zastosowanie w przypadku przekrojowych badań pieczęci jednej kategorii dysponentów w dłuższym okresie. Wówczas pozwala uchwycić okresowe zmiany stosunku ikono- i logosfery pieczęci, wynikające z czynników kulturowych czy prestiżowych. 
Na marginesie warto dodać, że schematy wzajemnych układów wyobrażenia i inskrypcji napieczętnej, które spotykamy na pieczęciach Czarnkowskiego, wykształciły się już w średniowieczu. Niewątpliwie najdawniejszą metrykę ma typ trzeci, charakterystyczny dla najstarszych polskich pieczęci, zarówno rycerskich, jak i innych dysponentów ${ }^{88}$. Układy drugi i pierwszy pojawiły się w późniejszym średniowieczu wraz z rozbudową umieszczanych na pieczęciach kompozycji heraldycznych ${ }^{89}$. Młodsze są układy czwarty i piąty. Spotykamy się z nimi na pieczęciach królewskich od czasów Kazimierza Jagiellończyka ${ }^{90}$. Na pieczęciach książąt mazowieckich takie rozwiązania są poświadczone dopiero od początków XVI w. ${ }^{91}$ Prawdopodobnie właśnie na przełomie XV i XVI w. doszło do ich recepcji wśród szlachty ${ }^{92}$. Wkrótce też stały się charakterystyczne dla szlacheckich pieczęci sygnetowych. Pieczęcie anepigraficzne z wyeksponowanym jedynie herbem właściciela znamy już ze średniowiecza ${ }^{93}$.

Inskrypcje znajdujące się na znanych pieczęciach Adama Sędziwoja Czarnkowskiego można podzielić na dwie kategorie: pierwsze odnoszą się do osoby dysponenta, służąc jego identyfikacji, drugie zaś dotyczą samej pieczęci, określając jej chronologię oraz charakter. Ich rozmieszczenie zostało omówione wyżej, stąd nie będziemy wracać do tego problemu. Wystarczy zaznaczyć, że napisy, które odnoszą się do właściciela pieczęci, były konsekwentnie sytuowane w otoku, oddzielonym od pola pieczęci zazwyczaj ciągłą linią (legenda). Takiej konsekwencji nie widać w przypadku drugiej kategorii. Inskrypcje mogły być bowiem umieszczane zarówno w polu pieczęci

${ }^{88}$ Zob. F. Piekosiński, Pieczęcie polskie wieków średnich, Kraków 1899, całość; J. Wroniszewski, dz. cyt., s. 241-247.

${ }^{89}$ Ten typ wyobrażenia występuje często na pieczęciach od drugiej połowy XIV w. J. Wroniszewski, dz. cyt., s. 246, s. 247, il. 7; zob. też Dokumenty strony polsko-litewskiej pokoju metneńskiego z 1422 r., wyd. P. Nowak, P. Pokora, Poznań 2004, gdzie liczne przykłady takich sigillów z pierwszej połowy XV w. (nr 2, 3, 13, 18, 19, 32, 46, 49, 77), oraz J. Grabowski, Z dziejów stosunków Polski z zakonem krzyżackim w Prusach (XIII-XVI w.), Warszawa 2006, gdzie pieczęcie tego typy z drugiej połowy XV w. (nr XVII, XVIII, XIX, XXI, XXIV, XXVI, XXVII, XXIX, XXXI, XXXIII).

${ }^{90}$ M. Gumowski, Pieczęcie królów polskich, Kraków 1910, s. 20, nr 31; Z. Piech, Monety, pieczęcie $i$ herby w systemie symboli wtadzy Jagiellonów, Warszawa 2003, s. 66.

${ }_{91}$ S. K. Kuczyński, Pieczęcie książą mazowieckich, Warszawa 1978, nr 65, 68, 78, 80.

92 Być może ten typ reprezentowała już pieczęć Grota z Ostrowa, znana z odcisku z 1462 r. J. Grabowski, dz. cyt., nr XLIII; zob. też uwagi J. Wroniszewskiego na temat genezy tego typu pieczęci: J. Wroniszewski, dz. cyt., s. 239.

${ }_{93}$ Z. Piech, Monety, s. 66. Przykłady pieczęci rycerskich: Dokumenty, nr 105; J. Grabowski, dz. cyt., nr XLI, XLII. 
(z obu stron wyobrażenia bądź też ponad nim), jak i znajdować się w polu otokowym.

$\mathrm{Na}$ napisy zaliczone do pierwszej kategorii składały się oba imiona dysponenta, jego nazwisko oraz tytulatura urzędnicza. Przyjrzyjmy się bliżej poszczególnym elementom. Pierwsze imię Czarnkowskiego podawano zawsze w pełnej formie ADAM. Trzeba podkreślić, że nie stanowiło to reguły obejmującej całą sfragistykę szlachecką - choćby na pieczęciach ojca naszego bohatera, Wojciecha Sędziwoja, pierwsze imię występowało w formie skróconej (ADALB. ${ }^{94}$. Praktyka skracania imienia jest także widoczna w legendach pieczęci kuzyna Adama Sędziwoja, Andrzeja Czarnkowskiego. Drugie imię, Sędziwój, w legendzie pieczęci Adama było już konsekwentnie skracane do form: SAD(ivoius), SADIW(oius), SAND(ivoius), [SA]DIV(oius). W materiale porównawczym z pełnym jego brzmieniem spotykamy się jedynie na pieczęci Jana Sędziwoja Czarnkowskiego, starosty drahimskiego. Kolejnym elementem legendy było nazwisko dysponenta. Na pieczęciach Adama Sędziwoja oddawano je w formie A CZARNKOW, niekiedy skracano do postaci A CZARN(kow), zazwyczaj występowało jednak w pełnym brzmieniu. Do interesujących wniosków prowadzi zestawienie pisowni nazwiska Czarnkowskich z pieczęci przedstawicieli różnych linii rodziny. Otóż widoczne na sigillach Adama Sędziwoja określenie a Czarnkow jest charakterystyczne wyłącznie dla reprezentantów jej młodszej linii. Z taką pisownią spotykamy się już na pieczęciach referendarza koronnego Stanisława Sędziwoja i starosty generalnego Wielkopolski Wojciecha Sędziwoja Czarnkowskiego, później na pieczęciach naszego Adama i jego brata Jana, starosty drahimskiego, a wreszcie na pieczęciach potomków Adama. Tymczasem przedstawiciele starszej linii używali nazwiska w formie Czarnkowski. Poświadczają to znane pieczęcie kuzynostwa Adama: Andrzeja i Piotra Czarnkowskich, a także ich stryja Andrzeja Czarnkowskiego, biskupa poznańskiego ${ }^{95}$. Takie rozróżnienie można również zauważyć w intytulacjach dokumentów oraz dedykacjach i tytułach druków poświęconych Czarnkowskim ${ }^{96}$. Charakterystyczny jest dokument

${ }_{94}$ Zob. przyp. 22.

${ }^{9}$ Zob. przyp. 29-34. Pieczęć biskupa Andrzeja Czarnkowskiego publikuje M. Gumowski, Handbuch der polnischen Siegelkunde, Graz 1966, Taf. XXXVII, nr 374; Dokumenty biskupa Andrzeja Czarnkowskiego: AP w Poznaniu, AMP, sygn. D 687 (z zachowaną mniejszą pieczęcią), D 690.

${ }^{96}$ Zob. np. AP w Poznaniu, AMP, sygn. D 151 (choć w podpisie: Czarnkowsky); AP w Szczecinie, AKS, sygn. I-482, k. 27 [1581]; k. 52 [1587]: Stanislaus Sandivogius a Czarnkow; k. 196 [1576]: Albertus Sandivogius a Czarnkow; k. 203 [1610]: Adam Sandiuogius a Czarnkow. Zob. też tytuły mów poświęconych Czarnkowskiemu: Gratulatio- 
z 1596 r., którym Adam Sędziwój Czarnkowski potwierdził sprzedaż kamienicy przez Piotra Czarnkowskiego. Na dyplomie nazwisko pierwszego z nich oddano jako a Czarnkow, drugiego zaś Czarnkowski a Czarnkow ${ }^{97}$. Znaczenie tej różnicy zostanie wyjaśnione niżej. Drugi człon inskrypcji tworzyła tytulatura urzędnicza. Jej postać zmieniała się wraz z kolejnymi awansami magnata. W zebranym materiale są widoczne dwie takie przemiany, wyznaczone cezurą 1606 r., kiedy to Czarnkowski otrzymał godność wojewody łęczyckiego i ustąpił ze starostwa pyzdrskiego ${ }^{98}$. Pieczęcie urzędnicze sprzed tej daty wymieniają tylko przynależne Czarnkowskiemu urzędy starosty generalnego Wielkopolski oraz starosty pyzdrskiego. Po 1606 r. na pierwsze miejsce wysuwa się urząd wojewody łęczyckiego, po nim dopiero następują w inskrypcji oba pojawiające się już wcześniej urzędy starościńskie. Świadectwem drugiej zmiany jest jedynie owalna pieczęć osobista, której legenda, oprócz województwa łęczyckiego i generalstwa wielkopolskiego, wymienia starostwo wolmińskie. Poszczególne elementy tytulatury urzędniczej Czarnkowskiego były oddawane za pomocą skróceń. Tytuł łęczycki przyjmował formy: PAL(atinus) LANC(iciensis) lub PAL(atinus) LAN(ciciensis). Inaczej tytuły starościńskie, które były ze sobą sprzężone przez wykorzystanie związku frazeologicznego wyrazu „starosta” z pozostałymi członami tytulatury. Kluczowy dla zrozumienia tego fragmentu legendy wyraz „starosta” - capitaneus, był umieszczany albo na końcu legendy, albo pomiędzy tytułem starosty generalnego Wielkopolski, zawsze rozpoczynającym tę część legendy, a kolejnym tytułem starościńskim, np. MAI[...] [CA]PIT(aneus); MAI(oris) PO(loniae) GE(eneralis) PIS(drensis) $\mathrm{CA}$ (pitaneus); MAI(oris) PO(loniae) GEN(eralis) CAP(itaneus) PIS(drensis); $\mathrm{MAIO}$ (ris) POL(oniae) GEN(eralis) $\mathrm{ET}$ PISDR(ensis) CAP(itaneus);

nes A. Sendivoii a Czarnkow, Poznań 1593; W. Czarnkowski, Pociecha Smętnemu Oycu, Iaśnie Wielmożnemu leo Mośći Panu, P. Adamowi Sedywoiowi z Czarnkowa Woiewodzie Lęczyckiemu Generalowi Wielgopolskiemu \&c. \&c. Staroście Miedzyrzeckiemu Pyzdrskiemu. Y Wszytkim Ich Mośćiom Panom z Czarnkowa po Ześćiu z tego Swiata Wielmożnego Ieo Mości Pana P. Wladislawa z Czarnkowa Starosty Bidgoskiego Pyzdrskiego \&c. \&c., Poznań 1623 . Niekiedy to nazwisko było pisane w nieco innej formie, łączącej obie jego wersje: z Czarnkowa Czarnkowski. Zob. M. Bembus, Pochwata pogrzebna stawney pamięci Jasnie Wielmożnego Ieo Mści Pana a Pana Adama Sędziwoja z Czarnkowa Czarnkowskiego, woiewody Leczyckiego, Generata Wielgopolskiego, Pyzdrskiego, Miedzyrzeckiego \&c., Kraków 1628.

${ }_{97}$ AP w Poznaniu, AMP, sygn. D 494.

98 Spisy urzędników wielkopolskich XVI-XVIII w. nie uwzględniają niegrodowego starostwa w Pyzdrach. Jedynym śladem rezygnacji Czarnkowskiego z tej godności jest jej brak w legendzie interesującej nas pieczęci, której odcisk pochodzi z 1627 r. 
MAIOR(is) POL(oniae) GEN(eralis) ET PISD(rensis) CAP; MAIO(ris) POL(oniae) GEN(eralis) WOL(minensis) CAP(itaneus). Poszczególne człony tej części inskrypcji, w całości brzmiącej Maioris Poloniae generalis [capitaneus] skracano do form: MAI(oris) PO(oloniae) GE(eneralis); MAI(oris) PO(loniae) GEN(eralis); MAIO(oris) POL(oniae) GEN(eralis); MA(ioris) POL(oniae) GEN(eralis); MAIOR(is) POL(oniae) GEN(eralis). Towarzyszącą "generalskiej” tytulaturze godność starosty pyzdrskiego oddawano przez skrócenia: PIS(drensis), PISD(rensis) bądź PISDR(ensis). Pojawiający się jednokrotnie tytuł starosty wolmińskiego oznaczono skrótem WOL(minensis). Stosowane w legendach sekwencja wyrazów i skrócenia tytułów nie odbiegają zatem od zwyczajów z epoki ${ }^{99}$.

Jak już wspomniano, drugą kategorią inskrypcji spotykanych na pieczęciach Czarnkowskiego są te, które łączą się z funkcjonowaniem typariusza. Należą do nich daty oraz napisy określające zakres merytoryczny pieczęci. Zdaniem Mariana Haisiga występujące na pieczęciach daty łączą się bądź to z wykonaniem typariusza, bądź też z wydarzeniem ważnym dla dysponenta pieczęci ${ }^{100}$. W naszym przypadku należy odnosić je do obu tych możliwości. Daty znajdowały się u góry odcisku i były kładzione albo w polu pieczęci, ponad wizerunkiem, albo umieszczane w polu legendy. W pierwszym przypadku wykonywano je cyframi o mniejszym module niż napisy w legendzie, $\mathrm{w}$ drugim natomiast wydzielano je dywizorami.

Inskrypcję informującą o zakresie funkcjonowania znamy tylko z jednej pieczęci Adama Sędziwoja. W odciskach uwierzytelniających ekstrakty z ksiąg grodu kaliskiego znajdują się sygle „D C” wskazujące na powiat kaliski. Usytuowano je w polu pieczęci, z obu stron tarczy herbowej, poniżej labrów. W porównaniu z pieczęciami późniejszych starostów generalnych, na których występuje taki element, jest to położenie nietypowe. $\mathrm{Na}$ siedemnasto- i osiemnastowiecznych sigillach inskrypcja ta znajduje się ponad tarczą herbową, na wysokości klejnotu, rozdzielającego oba jej elementy, bądź też ponad wyobrażeniem. Wówczas jest ona równoległa to linii oddzielającej pole pieczęci od pola legendy. Na pieczęci Czarnkowskiego inskrypcja została również najbardziej zredukowana. Na sigillach późniejszych zamiast sygli

99 Zob. też uwagi M. Adamczewskiego na temat legend pieczęci starościńskich. M. Adamczewski, dz. cyt., s. 20-24.

100 O znaczeniu dat umieszczanych w legendach pieczęci zob. M. Haisig, Studia nad legenda pieczęci miejskiej, Wrocław 1953, s. 69-73, oraz, dla warunków polskich, s. $126-130$. 
pojawiają się skrócenia wyrazów przez suspensję do formy DISTR lub DIST. $\mathrm{W}$ analogiczny sposób skracano nazwy stolicy powiatu ${ }^{101}$.

Kończąc rozważania poświęcone napisom napieczętnym, warto zauważyć, że na znanych pieczęciach Adama Sędziwoja Czarnkowskiego nie widać redukcji elementów składających się na inskrypcję (za wyją̧tkiem dat i określenia właściwości merytorycznych pieczęci) w zależności od rangi i funkcji danej pieczęci. Elementy legendy wskazujące na dysponenta typariusza są takie same na pieczęciach urzędniczych i osobistych. Wyjątkiem mogłyby być pieczęcie sygnetowe, na których z reguły napisy przyjmowały formę sygli oznaczających imię (imiona) i nazwisko właściciela, niekiedy uzupełnione o informacje dotyczące piastowanych przezeń urzędów ${ }^{102}$.

Inaczej było w przypadku znajdujących się na pieczęciach herbów. Tu w zależności od rangi pieczęci następowała redukcja wizerunku. W związku z tym umieszczane na pieczęciach Czarnkowskiego kompozycje heraldyczne można podzielić na trzy grupy: herb wielki, herb średni i herb mały.

Z herbem wielkim spotykamy się na pieczęciach większych Adama Sędziwoja Czarnkowskiego. Wyobraża on w tarczy herbowej skwadrowane herby Nałęcz i Poronia. Nad nią znajdują się dwa hełmy z klejnotami. Pierwszy z nich to pawi ogon przeszyty strzałą między dwoma jelenimi rogami, drugi zaś przedstawia pawi ogon umieszczony między dwoma bawolimi rogami zakończonymi proporczykami. Tarczę z obu stron podtrzymują gryfy. Całości kompozycji dopełniają labry.

Herb średni występuje zarówno na pieczęciach urzędniczych średnich, jak i prywatnych (mniejszych oraz, zapewne, sygnetowych) Czarnkowskiego. Wyobraża on w tarczy herbowej pomłośc. Nad tarczą znajduje się hełm z pierwszym z opisanych wyżej klejnotów, z obu stron tarczy są widoczne labry. Jest to najczęściej spotykany wizerunek herbu Czarnkowskich.

Wreszcie - funkcjonowania herbu małego możemy domyślać się na podstawie zachowanych odcisków sygnetów Stanisława Sędziwoja Czarnkowskiego i Piotra Czarnkowskiego. Wyobrażał on jedynie tarczę z godłem herbu Nałęcz.

Czarnkowscy od średniowiecza jako swego herbu używali Nałęcza w odmianie niewiązanej ${ }^{103}$. W czasach nowożytnych jego wizerunek często po-

${ }_{101}$ Zob. wyżej, przyp. 51.

102 Pominięto je w szczegółowych rozważaniach ze względu na fakt, że nie znamy odcisków takich pieczęci należących do Adama Sędziwoja.

103 F. Piekosiński, Heraldyka, s. 53, pieczęć Tomisława, kasztelana gnieźnieńskiego, brata Wincentego z Szamotuł, właściciela Czarnkowa; pieczęcie Jana z Czarnkowa: 
jawia się w związanych z Czarnkowskimi zabytkach pozasfragistycznych ${ }^{104}$. Specyfikę godła, rzadszego od Nałęcza wiązanego, członkowie rodziny mocno zresztą podkreślali ${ }^{105}$. Anonimowy autor rozprawki De origine et progressu familiae et dominorum $A$ Czarnkow, którym mógł być sam Adam Sędziwój Czarnkowski, pisał, że jeden z jego przodków miał udowadniać, iż „nie jest nałęnczanin związaney nałęnczy, którą to zwiazaną nałęcz zwano nodosam”. Co więcej, uważał, że jego herb został wtórnie utożsamiony z Nałęczem, pier-

B. Engel, Die mittelalterlichen Siegel der Fürsten, der Geistlichkeit und des polnischen Adels im Thorner Rathsarchive, Danzig 1902, s. 13, Taf. IV, nr 44.

104 To godło zostało szczególnie wyeksponowane na spiżowej płycie ufundowanej w 1602 r. przez Stanisława Sędziwoja Czarnkowskiego, znajdującej się w kościele parafialnym w Czarnkowie, gdzie pojawia się w zespole herbów fundatora, a poza tym zdobi chorągwie trzymane przez mitycznych protoplastów rodziny Czarnkowskich. Niedoskonałą podobiznę tablicy publikuje X. D., Pomnik Czarnkowskich w Czarnkowie, Przyjaciel Ludu, R. 2, nr 14, 1835, s. 108; fotografia całej tablicy, jak i jej detali znajduje się w Katalogu zabytków sztuki w Polsce, t. 5: Województwo poznańskie, z. 2: Powiat czarnkowski, oprac. I. Trybowski, O. Zagórski (dalej: Katalog zabytków Czarnków), Warszawa 1966, fot. 60-62.

${ }^{105}$ Jak się wydaje, dla współczesnych owa specyfika herbu Czarnkowskich nie była zupełnie jasna, skoro Andrzej Beklewski, autor panegiryku na okazję ślubu Piotra Działyńskiego z Jadwigą, córką Adama Sędziwoja Czarnkowskiego, wydanego w 1626 r., dziełko to zilustrował wyobrażeniem Nałęcza wiązanego, z postacią mężczyzny, z głową obwiązaną chustą, między dwoma jelenimi rogami w klejnocie. Zob. A. Beklewski, Panegyricus nuptialis in gratiam illustrium nouorum coniugum Pauli Dziatynski [...] et Hedvigis, illustrissimi D[omini] Adami Sandivogii Czarnkowski, comitis a Czarnkow, palatini Lanciciensis, Maioris Poloniae capitanei etc. etc. Filiae, Kraków 1626, k. A1. Także we współczesnych herbarzach pojawiają się przede wszystkim wyobrażenia Nałęcza wiązanego. B. Paprocki, Gniazdo cnoty, Kraków 1578, s. 21; tenże, Herby rycerstwa polskiego przez Bartosza Paprockiego zebrane i wydane r. p. 1584, wyd. K. J. Turowski, Kraków 1858 (dalej: Herby rycerstwa polskiego), s. 207; S. Jagodynski, Summariusz kleynotow abo herbow panstwa y rycerstwa Korony Polskiey y W. X. Litew [skiego] z roznych authorow: a mianowicie z Bielskiego, z Paprockiego y scriptow [...] zebrany, Kraków 1621, s. E2v; J. A. Gorczyn, Kleynoty abo herby panstwa y rycerstwa powiatow y miast gtownych Korony Polskiey y W. X. L. wedtug obiecadta dla pamięci tacnieyszey potożone, Kraków 1630, s. 67. Warto na tym tle podkreślić, że Szymon Okolski uznał herb Czarnkowskich za odmianę Nałęcza, którą określił jako Natęcz Primo i poświęcił mu osobny opis. Jego ilustrację stanowi poprawnie wykonany rysunek znaku używanego przez Czarnkowskich, uwzględniający wszystkie jego odmienności zarówno w godle, jak i w klejnocie. Zob. S. Okolski, Orbis Poloni Tomus II, in quo Antiqua Sarmatorum gentilitia et arma quaecunque a litera $L$, usque ad literam $R$, nclusive, suam incipiunt et recensent denominationem, continentur et dilucidantur, Kraków 1643, s. 243-247. Nałęcz „secundo” wyobraża herb w odmianie wiązanej z kobiecą postacią między jelenimi rogami w klejnocie. Zob. tamże, s. 248. 
wotnie zaś stanowił odrębny znak zwany Nałonie ${ }^{106}$. Herb spotykany w sigillach Adama Sędziwoja Czarnkowskiego wykazuje dalsze odmienności w stosunku do znaku używanego przez innych przedstawicieli heraldycznej wspólnoty Nałęczów. Charakterystyczny jest bowiem jego klejnot. Ów pióropusz przeszyty strzałą między jelenimi rogami jest właściwy tylko Czarnkowskim. Występuje on niemal wyłącznie na wyobrażeniach herbu młodszej linii tej rodziny ${ }^{107}$. Na zabytkach wyobrażających herb kuzyna Adama ze starszej linii Czarnkowskich, Andrzeja Czarnkowskiego, w klejnocie znajdują się jedynie dwa jelenie rogi ${ }^{108}$. Podobnie zwieńczona jest tarcza na jednej z pieczęci Piotra Czarnkowskiego ${ }^{109}$. Pozostawmy na chwilę zagadnienie klejnotu herbowego młodszej linii rodziny, by przyjrzeć się drugiemu herbowi występującemu na pieczęciach Adama Sędziwoja.

Kolejnym znakiem, pojawiającym się na pieczęciach magnata, jest herb Poronia. Funkcjonował on już w średniowiecznej Wielkopolsce, po czym, zdaniem J. Szymańskiego, zanikł w XVI w. ${ }^{110}$ Należy podkreślić, że jest on dość słabo poświadczony przez zabytki ikonograficzne. Jego wyobrażenia na zabytkach związanych z Czarnkowskimi należą do najpełniejszych. W tym kontekście spotykamy go dwukrotnie. Po raz pierwszy Poronia pojawia się na brązowej tablicy poświęconej przodkom Czarnkowskich, umieszczonej w czarnkowskiej farze, gdzie otwiera zespół herbów Barbary Pampowskiej, matki fundatora epitafium, Stanisława Sędziwoja Czarnkowskiego ${ }^{111}$. Wyobrażone tam godło przedstawia lilię heraldyczną, usytuowaną pomiędzy

106 De origine et progressu falimiae et d[ominorum] a Czarnkow, Biblioteka Kórnicka PAN, sygn. 306, k. 112. Zob. też M. Kazańczuk, Polskie legendy herbowe, Wrocław 1990, s. 64, gdzie legenda herbowa związana z Nałonie.

107 Zabytki pozasfragistyczne z takim wyobrażeniem: plakiety zdobiące lichtarze fundowane przez Adama Sędziwoja Czarnkowskiego w kościele parafialnym w Czarnkowie (po 1605 r.), Katalog zabytków Czarnków, s. 7; malowany herb na drzwiczkach zamykających portret trumienny Adama Sędziwoja Czarnkowskiego, tamże, s. 6; barwny wizerunek herbu na dokumencie fundacyjnym kolegiaty w Czarnkowie, AP w Poznaniu, Dokumenty i akta kościołów, sygn. 60; J. Choryński, dz. cyt., s. a1.

108 T. Jakimowicz, Renesansowe i manierystyczne rezydencje $w$ Wielkopolsce, Poznań 1971, s. 31, fot. 10; s. 32, fot. 11; s. 34-35, fot. 12-13; M. Strzałko, R. Kąsinowska, Wielkopolskie zamki, Poznań 2006, ilustracje na s. 59, 60, 61.

109 AArch w Gnieźnie, Zl, sygn. 290.

110 J. Szymański, Herbarz średniowiecznego rycerstwa, s. 233-234; tenże, Herbarz rycerstwa, s. 225.

111 X. D., dz. cyt., s. 108. Wykonany przez autora owej publikacji odrys jest jednak niedokładny, nie uwzględnia bowiem róż flankujących z obu stron wyobrażenie heraldycznej lilii. 
dwoma pięciopłatkowymi różami. Po raz drugi spotykamy się z nim właśnie na pieczęciach Adama Sędziwoja. Kształt samego godła Poroni, znajdującego się na tych zabytkach sfragistycznych, nie odbiega od innych znanych jego wyobrażeń. Nowość stanowi jednak wizerunek klejnotu: pawiego ogona między dwoma bawolimi rogami zakończonymi choragiewkami. Jest to jak dotąd jedyne znane przedstawienie takiej jego odmiany ${ }^{112}$. Warto zwrócić uwagę na charakterystyczny kontekst pojawienia się Poroni na pieczęci Czarnkowskiego. W standardowych układach heraldycznych mamy do czynienia z eksponowaniem herbów ojczystego i matczynego bądź też herbów ojczystego, matczynego i dopiero dalszych przodków właściciela herbu ${ }^{113}$. Tymczasem Czarnkowski eksponuje herb ojczysty i herb babki ojczystej z pominięciem herbu matczynego. Wiązało się to z określonymi funkcjami, które ów znak miał spełniać.

Powróćmy na chwilę do problemu klejnotu młodszej linii Czarnkowskich. Trudno ustalić, kiedy dokładnie doszło do wykształcenia się tej odmiany. Na znanych piętnastowiecznych pieczęciach rodziny pojawia się jeszcze klejnot wyobrażający jedynie dwa jelenie rogi ${ }^{114}$. Klejnot nie jest widoczny na nagrobku Macieja Czarnkowskiego, protoplasty starszej linii, znajdującym się w czarnkowskiej farze ${ }^{115}$. Prawdopodobnie umieszczony nad tarczą hełm wieńczy tylko korona. Natomiast już na pieczęciach Wojciecha Sędziwoja i Stanisława Sędziwoja Czarnkowskich, a więc bratanków Macieja, synów Sędziwoja Czarnkowskiego i Barbary Pampowskiej, wyobrażono klejnot w formie występującej także na pieczęci Adama Sędziwoja ${ }^{116}$. Trzeba tu zauważyć pewne niezdecydowanie przedstawicieli starszej linii rodziny. Wcześniej wspomniano, że na pieczęciach Piotra i Andrzeja Czarnkowskich w klejnocie pojawiają się najczęściej jedynie jelenie rogi. Wyjątek stanowi tu sigillum

112 J. Szymański nie zna zwieńczenia hełmu właściwego tego herbu. J. Szymański, Herbarz średniowiecznego rycerstwa, s. 233-234; tenże, Herbarz rycerstwa, s. 225, 241. Trzeba podkreślić, że pełny wizerunek tego herbu znajdował się już na pieczęci Ambrożego Pampowskiego (znana z lat 1505-1507), gdzie na hełmie umieszczono jednak trzy strusie pióra. Zob. B. Engel, dz. cyt., Taf. IV, nr 46.

113 P. Stróżyk, O potrzebie i możliwościach badań nad herbami ztożonymi. Uwagi na przyktadzie ikonograficznych źródet heraldycznych $z$ Wielkopolski, [w:] Ad fontes. O naturze źródta historycznego, red. S. Rosik, P. Wiszewski, Wrocław 2004, s. 207. Na stronach 201-203 autor zestawił literaturę tematu.

114 B. Engel, dz. cyt., s. 13.

115 Katalog zabytków Czarnków, s. 56, fot. 57.

116 I. W. Gronkowski, Opis dawniejszego kościota kolegiackiego a dzisiejszego parafialnego w Czarnkowie, jako też innych w obrębie parafii Czarnkowskiej dawniej i teraz znajdujących się kościotów filialnych i kaplic, Poznań 1886, s. 41. 
Piotra znane z odcisku uwierzytelniającego dokument dla mieszczanina wronieckiego, gdzie między rogami jest widoczny pawi ogon. Tymczasem na związanych z Andrzejem Czarnkowskim zabytkach heraldycznych z zamku w Osiecznej klejnot jego herbu występuje w dwóch wersjach: starszej i nowszej (z pawim ogonem przeszytym strzałą) ${ }^{117}$. Z kolei na plakiecie przytwierdzonej do drzwi dawnego skarbca kościoła czarnkowskiego znajduje się herb Wojciecha Czarnkowskiego (kasztelana śremskiego i rogozińskiego), ojca Piotra i Andrzeja, będący formą pośrednią między obu odmianami. Wyobraża on w klejnocie pawi ogon między jelenimi rogami. Brakuje mu jednak strzaty ${ }^{118}$. Jest więc analogiczny do przedstawienia znanego ze wspomnianej wyżej pieczęci Piotra Czarnkowskiego. Uderza podobieństwo formalne klejnotu używanego przez Pampowskich do „nowego” klejnotu Czarnkowskich, widoczne szczególnie w przypadku jego wersji pośredniej. I tu, i tam występuje pawi ogon pomiędzy zwierzęcymi rogami. Nie można zatem wykluczyć wpływu heraldyki Pampowskich na kształt tego elementu herbu wykorzystywanego w młodszej linii rodziny spowinowaconej włánnie z Pampowskimi. Data małżeństwa Barbary Pampowskiej z Sędziwojem Czarnkowskim (przed 1521 r.) stanowiłaby więc datę post quem dla powstania znaku. Prawdopodobnie do wykształcenia tej odmiany doszło jednak około połowy XVI stulecia, kiedy to wiek sprawny osiągnęła pierwsza generacja potomków Sędziwoja Czarnkowskiego i Barbary Pampowskiej (Stanisław Sędziwój Czarnkowski, Wojciech Sędziwój Czarnkowski). Owe wpływy heraldyki Pampowskich tłumaczyłyby ekskluzywizm znaku i przyjęcie go początkowo jedynie przez młodszą linię rodziny. Próby recepcji klejnotu przez przedstawicieli linii starszej można chyba wyjaśnić atrakcyjną legendą herbową związaną z owym klejnotem.

Interesującym elementem większego herbu Czarnkowskiego są gryfy pełniące funkcję trzymaczy herbowych. Nie spotykamy się z nimi na znanych pieczęciach innych przedstawicieli rodziny ani też na bardziej okazatych kompozycjach heraldycznych pochodzących z fundacji Czarnkowskich. Także inne zabytki heraldyczne związane z Adamem Sędziwojem nie zawierają tego elementu. Co prawda, trzymacze pojawiły się już w średniowiecznych pieczęciach rycerskich ${ }^{119}$, jednak nie występowały nazbyt często w pol-

117 T. Jakimowicz, dz. cyt., s. 31, fot. 10; s. 32, fot. 11; s. 34-35, fot. 12-13.

118 Zob. słabą fotografię zabytku w Katalog zabytków Czarnków, fot. 36; tę odmianę zna J. Szymański, odnosi ją jednak do Nałęcza wiązanego. Zob. J. Szymański, Herbarz rycerstwa, s. 193.

11 AP w Bydgoszczy, KNS, sygn. 78, pieczęć Piotra Szamotulskiego; M. Gumowski, Handbuch, Taf. L, nr 532, pieczęć Rafała Gołuchowskiego; nr 535, pieczęć Stani- 
skiej heraldyce szlacheckiej. W krajach Rzeszy Niemieckiej używanie tego elementu herbu było zastrzeżone właściwie dla reprezentantów szlachty tytularnej ${ }^{120}$. Być może dlatego egalitarne społeczeństwo szlacheckie odnosiło się do niego z rezerwą. Pojawienie się gryfów w herbie Czarnkowskiego, oprócz zaakcentowania pozycji społecznej właściciela, miało zapewne nieść ze sobą określone znaczenia związane z rodzinną tradycją.

Kończąc omawianie kompozycji heraldycznych widocznych na pieczęciach Adama Sędziwoja Czarnkowskiego, nieco uwagi należy poświęcić pozostałym ich elementom. Wśród nich na pierwszy plan wysuwają się hełmy. Hełmy wchodzące w skład herbów Adama Sędziwoja to zawsze, charakterystyczne dla epoki nowożytnej, hełmy prętowe. Na pieczęciach średnich, mniejszych i sygnetowych tarczy herbowej z jednym godłem towarzyszył jeden hełm wyobrażony en face. Inaczej było na pieczęci większej, na której nad tarczą znajdowały się dwa hełmy zwrócone ku sobie w geście kurtuazji heraldycznej. W Polsce, niezależnie od liczby godeł umieszczonych w tarczy herbowej, towarzyszył jej z reguły jeden hełm z klejnotem właściwym dla herbu rodowego danej osoby. $\mathrm{Z}$ taką sytuacją spotykamy się też w przypadku złożonych herbów innych Czarnkowskich, kładzionych zarówno na pieczęciach, jak i innych przedmiotach ${ }^{121}$. Warto jednak zauważyć, że osiemnastowieczny heraldyk Józef A. Jabłonowski odnotował przekonanie, podzielane przez szlachtę, iż każdemu polu tarczy herbowej powinien odpowiadać jeden hełm z klejnotem umieszczonym nad tarczą ${ }^{122}$. Według Maximiliana Gritznera w krajach niemieckich liczba hełmów usytuowanych na skraju tarczy powinna odpowiadać liczbie wyobrażonych na tarczy godeł ${ }^{123}$. Z czasem ten zwyczaj został sformalizowany, a liczba hełmów towarzyszących tarczy herbowej

sława Ostroroga. J. Wroniszewski, za P. Mrozowskim, jako pierwszy przykład zastosowania trzymaczy herbowych wskazuje herb na pieczęci Mikołaja, wojewody kaliskiego, z 1305 r. Zob. J. Wroniszewski, dz. cyt., s. 245. M. Adamczewski podkreśla, że na pieczęciach starościńskich z terenów Polski środkowej trzymacze pojawiają się dopiero w XVIII w. Zob. M. Adamczewski, dz. cyt., s. 35-37.

120 W. Strzyżewski, dz. cyt., s. 123.

${ }_{121}$ Zob. wyżej opisy pieczęci Andrzeja Czarnkowskiego. Podobnie na plakiecie z herbem Wojciecha Czarnkowskiego, umieszczonej na wejściu do zakrystii w kościele parafialnym w Czarnkowie, usytuowano tarczę czteropolową: w polu pierwszym znajduje się godło herbu Nałęcz w odmianie używanej przez Czarnkowskich, w polu drugim i trzecim godło h. Łodzia, w czwartym godło h. Poraj. Sekwencję herbów podaje I. W. Gronkowski, dz. cyt., s. 18.

122 J. A. Jabłonowski, Heraldica to jest osada kleynotow rycerskich y wiadomosc znakow herbownych dotad w Polszcze nieobiasniona, Lwów 1742, s. E5.

123 W. Strzyżewski, dz. cyt., s. 108, przyp. 58. 
zaczęła wskazywać na rangę osoby: jeden hełm przysługiwał szlachcie nietytularnej, dwa hełmy szlachcie posiadającej tytuł rycerza bądź wolnego pana (barona), trzy hełmy zdobiły herby hrabiowskie, cztery zaś książęce ${ }^{124}$. Obie te zasady nie były jednak konsekwentnie przestrzegane: na pieczęci księcia pomorskiego Joachima Fryderyka datowanej na 1570 r. spotykamy nad dziewięciopolową tarczą jedynie trzy hełmy ${ }^{125}$. Także trzy hełmy znajdują się nad czteropolową tarczą herbową książąt legnicko-brzeskich, ze skwadrowanymi godłami ${ }^{126}$. Konstrukcja herbu umieszczonego na większej pieczęci Adama Sędziwoja Czarnkowskiego może świadczyć o znajomości zwyczajów heraldycznych panujących wśród wyższej szlachty Rzeszy, które możny wykorzystał do podkreślenia swej pozycji społecznej. Ten domysł zdaje się potwierdzać informacja podana przez samego Czarnkowskiego, że w jego bibliotece znajdował się , ieden gradal tak wielkie w czerwonym axamicie zpuklami y z klauzurami srebrnemi częscią po łacinie, częscią oną starą dziwną Polsczyzną pisane, gdzie były y familiae y herby wypisane, y wymalowane, ktorych ledwo trzecia czesść zostala y to drugie czudzoziemskie, gdy się tu ludzie do Polski, z czudzych kraiow znosili”'127. Nieszczęściem owa księga herbowa spłonęła w czasie pożaru zamku szubińskiego w pierwszej połowie XVII w.

\section{PIECZĘĆ JAKO NOŚNIK PAMIĘCI HISTORYCZNEJ}

Pieczęć może stać się nośnikiem pamięci historycznej na dwa sposoby: wtórnie, kiedy ma poświadczać jakieś wydarzenie z przeszłości niezależnie od treści zapisanych w jej legendzie i wizerunku ${ }^{128}$, bądź też celowo, kiedy

124 Tamże, s. 109-110.

125 M. Gumowski, Pieczęcie książąt pomorskich, Zapiski Towarzystwa Naukowego w Toruniu, t. 16, z. 1-5, 1950, nr 98; K. Bobowski, Dawne pieczęcie na Pomorzu Zachodnim, Szczecin 1989, fot. 19.

126 M. Kaganiec, Heraldyka Piastów śląskich 1146-1707, Katowice 1992, s. 122.

127 De origine..., s. 111v-112.

128 Charakter pieczęci, którą uwierzytelniano dokumenty wystawiane dla członków rodziny, miał niekiedy wskazywać na ich pozycję społeczną lub szczególną łaskę wystawcy dokumentu. Tak można interpretować wzmiankę o przywieszeniu kontrsigillowanej sygnetem władcy pieczęci tronowej Witolda do uwierzytelnienia dokumentu dla rodziny Zenowiczów, znajdującą się w testamencie Krzysztofa Despota Zenowicza z 1611 r.: „naprzedniejszy jest przywilej na pergaminie Witoldow, alias Aleksandrow, z majestatową wielką pieczęcią zawieszony, na której pieczęci majestatowej z drugiiej strony małą signitową pieczęcia własną samego Witolda Książęcia Litewskiego przyciśnioną (co nie jest w każdym przywileju) ale wielką nowiną w domu szlacheckim mieć”. 
to właśnie umieszczone na niej wizerunki czy inskrypcje mają wskazywać na jakieś ważne dla dysponenta zdarzenie ${ }^{129}$. Można to odnieść oczywiście również, a może przede wszystkim, do pieczęci herbowych. Jak zauważył A. Wyrobisz, w Polsce nowożytnej herby były bowiem nie tylko znakami komunikacji społecznej, pozwalającymi na identyfikację właściciela, wskazanie jego przynależności stanowej czy więzów łączących go z innymi członkami społeczeństwa, ale też środkiem umożliwiającym przekazywanie bardziej złożonych treści, jak ideologia polityczna, historia kraju bądź rodziny, czy wreszcie „sygnalizowanie układów i ugrupowań” opartych na więzach rodzinnych ${ }^{130}$. W tym kontekście niezwykle ciekawie jawi się przekaz zakodowany na pieczęciach Adama Sędziwoja Czarnkowskiego. To spostrzeżenie dotyczy nie tylko umieszczanego na pieczęciach herbu, szczególnie herbu większego, ale także niektórych elementów legendy napieczętnej. Kluczem do zrozumienia przesłania zakodowanego na pieczęciach Czarnkowskiego jest tradycja historyczna jego rodziny.

Funkcjonowanie tradycji historycznej Czarnkowskich w XVI w. jest już dobrze poświadczone. Dla Bartosza Paprockiego stała się ona podstawą do stworzenia legendy opisującej początki herbu Nałęcz ${ }^{131}$. Niewątpliwie istniała ona jednak wcześniej. W ujęciu znanym z drugiej połowy XVI w. jej szkielet stanowiły tzw. falsyfikaty czarnkowskie, powstałe około połowy tego stulecia, stworzone prawdopodobnie przez Stanisława Sędziwoja Czarnkowskie-

U. Augustyniak, Testamenty ewangelików reformowanych $w$ Wielkim Księstwie Litewskim, Warszawa 1992, s. 110.

129 Jako przykład można podać tu choćby wymienianie w inskrypcji dat ważnych dla dysponenta.

130 A. Wyrobisz, Polska heraldyka nowożytna - na pograniczu historii spotecznej, historii sztuki i historii literatury, [w:] Heraldyka i okolice, red. A. Rachuba, S. Górzyński, H. Manikowska, Warszawa 2002, s. 140. Ta problematyka ma już swoją literaturę. Zob. np. S. Baczewski, Mit początku i wtadza szlachty. Dyskurs genealogiczno-historyczny w XVII-wiecznych kazaniach pogrzebowych, Wschodni Rocznik Humanistyczny, t. 3, 2006, s. 37-55; M. Kazańczuk, O herbach szlacheckich $w$ dawnej Polsce, Nauka, t. 4, 2006, s. 117-127. Tam wcześniejsze publikacje.

131 Bartosz Paprocki znał dwie wersje opowieści o początkach herbu Nałęcz. Pierwsza jest tożsama z legendą o początkach rodu Czarnkowskich. Według drugiej znajdującą się w godle chustę miał wiązać na głowach rycerzy Bolesław Krzywousty po przegranej bitwie z Rusinami pod Haliczem. Herby rycerstwa polskiego, s. 207. Przy czym w Gnieździe cnoty podaje jedynie pierwszą jej wersję. B. Paprocki, Gniazdo, s. 21; J. Pakulski, Natęcze, s. 16. Pierwszą wersję szczegółowo analizuje M. Kazańczuk, Staropolskie legendy, s. 64 i n. Drugą wersję legendy herbowej S. Okolski odnosi do herbu Nałęcz „secundo" (z wiązaną pomłością w godle oraz kobiecą postacią między jelenimi rogami w klejnocie). S. Okolski, dz. cyt., s. 248. 
go. Zespół owych dokumentów obejmuje: nadanie przez Mieszka Starego Czarnkowa hrabiemu [komesowi] Mikołajowi w 1192 [1202] r. ${ }^{132}$, kolejne nadanie dla Sędziwoja z Czarnkowa, które miał poczynić Bolesław Pobożny w $1245 \mathrm{r}^{133}$, i potwierdzenie tego dyplomu przez Władysława Łokietka w 1323 r. ${ }^{134}$, dokument Kazimierza Wielkiego dotyczący zwrotu rodzinie Czarnkowa z 1343 r. ${ }^{135}$, kolejny dokument tego władcy, datowany na 1362 r., mający zatwierdzać podział dóbr między braci Czarnkowskich ${ }^{136}$, dokument z 1381 r. lokujący wieś Trzebinia w okolicach Człopy ${ }^{137}$, nadanie wsi Przelewice Szymonowi Trzebince ${ }^{138}$, wreszcie dokument Władysława Jagiełły, datowany na 1430 r., zwracający Janowi Czarnkowskiemu i Jakubowi Kniszewickiemu wieś Gulcz ${ }^{139}$. Ten zestaw należy uzupełnić o jeszcze jeden hipotetyczny dokument: wyrok sądu królewskiego z czasów Władysława Łokietka, pozbawiony daty rocznej, lecz zawierający miejsce datacji (Datum in Campis circa Suleiow), wzmiankowany przez Kaspra Niesieckiego ${ }^{140}$, ale znany już wcześniej autorowi rękopiśmiennej historii rodziny pod tytułem De origine... pochodzącej z początków XVII w. W przeciwieństwie do pozostałych dotyczy on nie posiadłości Czarnkowskich, ale oczyszczenia rodziny z zarzutu udziału w zabójstwie króla Przemysła II. Te falsyfikaty można podzielić na dwie grupy: jedne miały charakter wyłącznie użytkowy, stanowiąc, na co wskazali autorzy hasła „Czarnków” w Stowniku historyczno-geograficznym województwa poznańskiego w średniowieczu, dowód w sporach majątkowych, drugie zaś obok tego, bądź wyłącznie, ilustrowały historię rodu. Do drugiej grupy można zaliczyć fałszerstwa datowane na lata 1192 i 1245 , wyrok Łokietka w sprawie zabójstwa Przemysła II, wreszcie dokumenty Kazimierza Wielkiego z 1343 i 1362 r. Służyły one nie tylko określeniu zakresu i charakteru posiadania Czarnkowskich w poszczególnych dobrach, ale też (a może przede wszystkim) uwierzytelniały autorytetem nominalnych wystawców ważne wydarzenia z dziejów familii. Odwołują się do nich wszyscy dziejopisarze, odtwarzający historię rodziny, przepisując niekiedy dosłownie,

132 Kodeks dyplomatyczny Wielkopolski, t. I-IV, wyd. T. Zakrzewski; t. V, wyd. F. Piekosiński; t. VI-XII, wyd. A. Gąsiorowski i in., Poznań 1864-1999; tu: t. VI, nr 2.

133 Tamże, t. I, nr 249.

134 Tamże, t. II, nr 1037.

135 Tamże, t. VI, nr 131.

136 Tamże, t. VI, nr 199.

137 Tamże, t. VI, nr 271.

138 Tamże, t. VII, nr 701.

139 Tamże, t. IX, nr 1242.

140 K. Niesiecki, Herbarz Polski, t. 3, wyd. J. Bobrowski, Lipsk 1839, s. 202-203. 
jak Mateusz Bembus, obszerne ich fragmenty ${ }^{141}$. Stosunek tradycji rodowej do falsyfikatów czarnkowskich trudno określić bez szczegółowych badań. Nie wiemy, czy to falsyfikaty stały się inspiracją do stworzenia opowieści o dziejach Czarnkowskich (wtedy historia rodu dodatkowo miałaby uwierzytelniać informacje podawane przez fałszerza), czy też twórca falsyfikatów odwoływał się do jakiejś istniejącej już historii rodziny, z której zaczerpnął imiona postaci, mających być odbiorcami owych dokumentów. Pewną wskazówką zdaje się wzmianka o księdze herbowej, w której „były y familiae y herby wypisane, y wymalowane"142. A więc mogła ona zawierać jakieś elementy tradycji rodzinnej. To, że według działającego w początkach XVII w. autora owej rozprawki miała być spisana „częscią po łacinie, częscią oną starą dziwną Polsczyzną", wskazuje na jej dawną metrykę, sięgającą, być może, początków XVI w. Pozwalałoby to na wniosek, że tradycja rodzinna poprzedzała sporządzenie falsyfikatów. Jest to jednak bardziej domysł aniżeli nawet hipoteza.

Niewątpliwie w drugiej połowie XVI w. opowieść o dziejach Czarnkowskich była już, przynajmniej w ogólnych zarysach, ukształtowana. Co istotne, zarówno hipotetyczne autorstwo zbioru falsyfikatów, jak i wszystkie przekazy narracyjne, które powstały w kręgu Czarnkowskich, wskazują na szczególne zainteresowanie własną historią przedstawicieli młodszej linii rodziny ${ }^{143} \cdot \mathrm{Na}-$

${ }_{141}$ Do dokumentu z 1343 r. odwołuje się B. Paprocki w Gnieździe cnoty, wspominając o zamianie Czarnkowa na Rogoźno. Bałamutna jest jednak podana przezeń informacja, że później za Rogoźno mieli otrzymać Szubin. Ten wszedł w skład posiadłości rodowych dopiero w XV w. (Z. Górczak, Rozwój, s. 190). Powoływanie się na przywiley stary mający poświadczać tę transakcję jest albo figurą retoryczną, albo też zniekształconym echem dokumentu z 1343 r. Zob. B. Paprocki, Gniazdo, s. 22. Co ciekawe, ani w Gnieździe cnoty, ani też w Herbach rycerstwa nie pojawiają się tak ważne dla tradycji rodowej postacie, jak Mikołaj, dwunastowieczny wojewoda kaliski, czy kolejni Sędziwojowie mający żyć w XIII i XIV w. Zob. B. Paprocki, Gniazdo, s. 22; Herby rycerstwa polskiego, s. 207-211. Może to wskazywać na to, że opowieść o początkach Czarnkowskich była znana Paprockiemu tylko w ogólnym zarysie. S. Okolski cytuje fragment dokumentu z 1192 r., a zna falsyfikaty z 1245 i 1343 r. S. Okolski, dz. cyt., s. 245-246. Wszystkie te dokumenty przywołuje i cytuje M. Bembus, dz. cyt., s. 12, 13, 14; dokument Mieszka Starego z 1192 r., wyrok Łokietka w sprawie zabójstwa Przemysła, przywilej Kazimierza Wielkiego z 1343 r. zna autor rękopiśmiennego dziełka De origine..., s. 111v-112v. J. Choryński, dz. cyt., s. C2, powołuje się na dokumenty z 1192 r., 1245 r., wzmiankuje też zamianę Czarnkowa na Rogoźno.

${ }^{142}$ De origine..., k. 111v-112. Zapewne stąd, nie zaś z druku Choryńskiego, informację tę wziął K. Niesiecki. K. Niesiecki, dz. cyt., s. 202.

143 Przypomnijmy, że autorstwo falsyfikatów przypisuje się Stanisławowi Sędziwojowi Czarnkowskiemu. K. Górska-Gołaska, Dobra Natęczów, s. 193-194; Stownik historyczno-geograficzny województwa poznańskiego w średniowieczu, cz. 1, z. 2, red. A. Gą- 
leży podkreślić, że opowieść o wczesnych dziejach Czarnkowskich stanowiła najbardziej rozbudowaną legendę mówiącą o początkach familii pieczętującej się Nałęczem. Co ciekawe, tak jak zestawione przez Paprockiego genealogie innych rodzin przypisanych do tego herbu sięgają co najwyżej XIII w., tak protoplaści właścicieli Czarnkowa mieli występować już w IX w. To właśnie spowodowało, że, jak już wspomniano, ów heraldyk odwołał się do nich, tworząc legendę herbu Nałęcz, mającą odnosić się do wszystkich herbownych. $\mathrm{Z}$ prac Paprockiego ta opowieść została przejęta przez autorów innych herbarzy, ulegając dalszej rozbudowie i modyfikacjom ${ }^{144}$.

Dla interpretacji wizerunków znajdujących się na pieczęciach Adama Sędziwoja Czarnkowskiego największe znaczenie ma jednak tradycja funkcjonująca w jego rodzinie. Dysponujemy aż czterema jej przekazami, powstałymi w kręgu Czarnkowskich. Najstarszym jest inskrypcja umieszczona na tablicy poświęconej pamięci przodków, ufundowanej w 1602 r. przez Stanisława Sędziwoja Czarnkowskiego, znajdującej się w czarnkowskim kościele ${ }^{145}$. Wy-

siorowski, Wrocław 1982, s. 289-290, 294, przyp. 3. On też jest fundatorem tablicy upamiętniającej przodków Czarnkowskich, będącej najstarszą kodyfikacją tradycji powstałej w kręgu rodziny. Jej rozszerzone wersje znajdujemy w mowach poświęconych Adamowi Sędziwojowi Czarnkowskiemu. Wreszcie z młodszą linią, w której rękach znajdował się Szubin, wzmiankowany w rękopisie, trzeba łączyć pracę De origine... Jednocześnie nie znamy takich zabytków związanych ze starszą linią rodziny.

144 Pewne modyfikacje w stosunku do „kanonicznej” wersji znajdujemy już w pracach Paprockiego, który w Gnieździe cnoty protoplastą rodu uczynił Gniewomira, nie zaś Dzierżykraja (B. Paprocki, Gniazdo, s. 21, zob. s. 22, gdzie wywodzi genealogię rodziny od Dzierżykraja, mającego żyć około 890 r.). Wycofał się z tego już w Herbach rycerstwa polskiego, s. 207. Dalsze modyfikacje znajdujemy w późniejszych pracach. Trudno powiedzieć, czy lista potomków mającego żyć w IX w. Dzierżykraja z Człopy, pojawiająca się w Gnieździe cnoty, jest autorstwa Paprockiego, czy też stanowi odbicie tradycji rodowej, choć bardziej prawdopodobna wydaje się pierwsza możliwość. Kodyfikacje historii rodziny powstałe w kręgu Czarnkowskich nie notują wymienionych tam postaci, a z drugiej strony nie zostały tam wymienione postacie ważne dla Czarnkowskich. S. Okolski, powołując się na Paprockiego, wywodził Czarnkowskich od księcia Popiela. S. Okolski, dz. cyt., s. 243-245. Trzeba też wskazać na koncepcję Kaspra Niesieckiego, który autorsko wywiódł Dzierżykraja z Człopy od potomków mitycznego Leszka (K. Niesiecki, dz. cyt., s. 205), czy też dziełko J. I. Bocheńskiego, działającego w końcu XVIII w. historyka regionalisty związanego z ziemią wałecką, który z imienia mitycznego protoplasty rodu - Dzierżykraja, uczynił pierwotne nazwisko późniejszych właścicieli Czarnkowa. Przed 1192 r. mieli się oni nazywać de Dzierzykraj. Zob. J. I Bocheński, Historia kościota parafialnego $w$ Watczu spisana na podstawie prawdziwych dokumentów i wiarygodnych autorów, oprac. L. Bąk, M. Hlebionek, A. Szweda, Wałcz 2002, s. 58-60.

145 Katalog zabytków Czarnków, s. 6, fot. 60-62. Napis i rysunek tablicy publikuje X. D., dz. cyt., s. 108-109. Samą inskrypcję przywołuje J. Łukaszewicz, Opis histo- 
mienia ona protoplastów rodziny wraz ze wskazaniem na ich zasługi. Kolejny to przywoływane tu często dziełko De origine... ${ }^{146}$. Jego autorem może być sam Adam Sędziwój Czarnkowski, ostatni męski przedstawiciel rodu będący właścicielem Szubina, gdzie wspomniana praca miała powstać. Dzieło zostało napisane po pożarze zamku szubińskiego, w którym miało spłonąć archiwum rodowe, przeniesione tam przez Czarnkowskiego z rodzinnego Czarnkowa. Niestety, precyzyjne ustalenie daty tego wydarzenia na podstawie literatury okazało się niemożliwe ${ }^{147}$. Wreszcie - dwa kolejne świadectwa zostały wplecione w mowy pogrzebowe ku pamięci Adama Sędziwoja Czarnkowskiego, wygłoszone przez J. Choryńskiego ${ }^{148}$ i M. Bembusa ${ }^{149}$. Te prace pozwalają na odtworzenie tradycji rodowej w takiej formie, w jakiej funkcjonowała ona w kręgu rodziny w czasach Adama Sędziwoja Czarnkowskiego.

Opowieść rozpoczynała się w czasach Bolesława Chrobrego. Wtedy to miał żyć władający Człopą, miastem wchodzącym w skład późniejszych dóbr czarnkowskich, książę Dzierżykraj. Miał on zostać nawrócony i ochrzczony przez Bolesława Chrobrego ${ }^{150}$. Tradycja mocno akcentowała fakt jego pomor-

ryczny kościotów parochialnych, kościótków, kaplic, klasztorów, szkótek parochialnych, szpitali i innych zaktadów dobroczynnych $w$ dawnej diecezyi poznańskiej, t. 1, Poznań 1858, s. 186-187. Warto zauważyć, że zdaniem Łukaszewicza treść inskrypcji stanowi przejaw starczej demencji Stanisława Sędziwoja Czarnkowskiego. W tłumaczeniu na język polski: I. W. Gronkowski, dz. cyt., s. 41.

146 De origine..., k. 111v-112v.

147 Zob. B. Janiszewska-Mincerowa, F. Mincer, W okresie staropolskim, [w:] Dzieje Szubina, red. M. Biskup, Warszawa-Poznań 1974, s. 31-46, nie notują żadnego pożaru zamku przed połową XVII w. Tak samo Katalog zabytków sztuki w Polsce, t. 9: Dawne województwo bydgoskie, z. 14: Szubin i okolice, oprac. M. Lewicka, B. Szymanowska, Warszawa 1977, s. 44.

148 J. Choryński, dz. cyt.

${ }_{149}$ M. Bembus, dz. cyt.

150 Tablica w kościele parafialnym: zob. I. W. Gronkowski, dz. cyt., s. 41: „pochodzącemu od Dzierżykraja pana na Człopie, przez Bolesława Chrobrego, pierwszego króla polskiego do wiary Chrystusowej nawróconego i ochrzczonego"; De origine..., k. 112: w XIV w. jeden z Czarnkowskich przed Łokietkiem „wywodził originem et genealogiam suam a Dorzycraio D[omin]no Czlapensi, którego Chabry Bolesław krol na wiarę na wrócił [!] Chrzescianską y okrzcił”; M. Bembus, dz. cyt., s. 10: „Pierwszy tey Familiey Przodek (co poważny napis na iednym grobie w tym kościele oświadcza) był Dzierżykray Ksiązę na Szłoppie”. Ten autor nie podaje informacji o chrzcie, wspomina tylko, że już za Mieszka I jeden z Dzierżykrajów świadczył na dokumencie fundacyjnym Trzemeszna (falsyfikat). Sekwencja postaci wymienianych przez Bembusa pokazuje, że datuje on chrzest Dzierżykraja raczej na okres przed 966 r., a więc analogicznie do Paprockiego Gniazda cnoty. J. Choryński wskazuje jako chrzciciela Bolesława Chrobrego, ale nie podaje imienia postaci; J. Choryński, dz. cyt., s. C2. 
skiego pochodzenia. „Były to książęta Szłopskie narodu Pomorskie[g]o nie Polskie[g]o, i owszem za poganstwa wielkie z Polaki woyny wiedli” - pisał Bembus. Następnie opowieść przybliżała okoliczności otrzymania przez panów z Człopy Czarnkowa, który miał stać się główną siedzibą rodu. Pojawiające się w pracy Bembusa informacje o kolejnych Dzierżykrajach występujących w źródłach zostały zapewne zaczerpnięte przezeń z dzieł Paprockiego ${ }^{151}$. Gród czarnkowski początkowo miał znajdować się w rękach niejakiego Gniewomira, niespokrewnionego z człopskimi Dzierżykrajami: „ale jako grabiowie Szłopscy przeszłych wiekow Czarnkowa nie mieli, tak Gniewomira krwią bynaymniej nie tykali" - zanotował Bembus. Ponieważ Gniewomir zdradził Bolesława Krzywoustego, gród został mu odebrany i wrócił w ręce władców Polski ${ }^{152}$. Dopiero Mieszko Stary w 1192 r. nadał go potomkowi Dzierżykraja człopskiego, Mikołajowi, wojewodzie kaliskiemu. Ów miał założyć przy czarnkowskim grodzie miasto ${ }^{153}$. Kolejnym wydarzeniem odnotowanym

${ }^{151}$ M. Bembus, dz. cyt., s. 10-11. Zob. B. Paprocki, Gniazdo, s. 22.

${ }^{152} \mathrm{Na}$ temat Gniewomira, który był postacią historyczną, pisał ostatnio E. Rymar, Rodowód ksiażąt pomorskich, Szczecin 2005, s. 90.

153 Tablica w kościele parafialnym: I. W. Gronkowski, dz. cyt., s. 41: „panu Mikołajowi, hrabiemu i baronowi, wojewodzie kaliskiemu, nabywcy zamku Czarnków od Mieczysława V księcia wielkopolskiego w r. 1192, i miasta tego założycielowi i pierwszemu właścicielowi”. De origine..., k. 112: „Z tąd biore originem et progressum vsq[ue] ad Meczlau[m] V Ducem Maioris Poloniae senem, który Nicolao Comiti et Baroni Palatino Callisien[si] Castrum Czarnkow contulit iure haereditario perpetuo cum facultate noueciuitatis condendae eodem nomine uocanda cum autoritate magna et parua Judicia exercere, bellum duorum commitere, et examen aquae frigidae et feruentis [...] który Czarnkow pierwey per confisactionem przyszedl do rąk Xiązecich, po Gniewomirze dziedziczu iego punitum propter crimen perfidiae, az do tego Meclau[a] V, który to dał iey ut supra Nicolao Comiti et Baroni”; M. Bembus, dz. cyt., s. 11: „Wieku pierwszego po tysiącznym żył Mikołay woiwoda Kaliski. Ten za posługi swe znaczne y życzliwe wziął darowizną od Mieczysłąwa ksiazęcia Polskiego zamek Czarnkow na wieczność. Był to zamek przedtym Gniewomirow, ale jako grabiowie Szłopscy przeszłych wiekow Czarnkowa nie mieli, tak Gniewomira krwią bynaymniej nie tykali. Utracił on dla zdrady swoiey Czarnkow: a grabiowie go ze Szłopy za wierne posługi swe ku Panu niedziedzicznym jakim spadkiem otrzymali. Na darowizne Czarnkowa iest na Czarnkowskim Domu poważny przywiley w te słowa: Nos Miecislaus quintus dei gratia Dux Poloniae; notum facimus [...] datum in Rogozno in crastino b. viti, Anno Gratiae Domini 1192 Tamże w tym przywileiu pozwala ksiazę Woiewodzie Czarnkowskiemu miasto targowe założyć”; J. Choryński, dz. cyt., s. C2: „Za czasu bowiem Mieczysława Xiążęcia Wielkiey Polskiey Piątego Mikołay comes et Baro Woiewoda Kaliski Roku Panskiego 1192 Zamku Czarnkowskiego dostawszy, y tam miasto budowane y dostatnie zbudowawszy, roznemi godnosciami od tegosz Xiążęcia za zasługi swoie y cnote uczestowanym y udarowanym został". 
przez rodową historię jest otrzymanie przez Sędziwoja Czarnkowskiego, zazwyczaj utożsamianego z synem wojewody Mikołaja, zespołu dóbr położonych na północ od Noteci, co miało nastąpić w $1245 \mathrm{r} .{ }^{154} \mathrm{Na}$ czasy panowania Władysława Łokietka tradycja datuje dwa istotne fakty. Pierwszy z nich - zamianę Czarnkowa na Rogoźno - wzmiankują wszystkie wersje opowieści, przypisując ją Sędziwojowi, kasztelanowi międzyrzeckiemu ${ }^{155}$. Jako powód tejże zamiany podają zazwyczaj potrzebę umocnienia granic królestwa przed napadami wrogów, niekiedy identyfikując ich jako Pomorzan lub margrabiów brandenburskich ${ }^{156}$. Czarnków miał powrócić w ręce Nałęczów za spra-

154 Tablica w kościele parafialnym: I. W. Gronkowski, dz. cyt., s. 41: „którego syn hrabia Sędziwój od księcia Bolesława wsie Gulcz, Białę i Rozdruszgę w r. 1245 w darze dziedzicznym nabył”. W De origine... ten epizod został pominięty; M. Bembus, dz. cyt., s. 13: „SEDZIWOY Grabia z Czarnkowa, syn wyżey pomienionego woiewody kaliskiego: znac iż oyca nie wydał, ale iego tropem poszedł; bo w nagrode posług swoich wiernych otrzymał od Bolesłąwa Książęcia Polskiego niemałe maietności, iako Gołężą y Białą także na wieczność, Anno Domini 1245, czemu teraz iest lat 383”. Na marginesie warto zauważyć, że wydarzenia z okresu 1192-1245 Bembus uzupełnia o informację na temat udziału Czarnkowskich w buncie przeciw panowaniu Bolesława Rogatki, do którego miało dojść w 1242 r. (s. 13): „Wtorego wieku po tysięcznym to iest circa Annum Domini 1242 żył Bogumił Dzierżykray, woiewoda Poznański, któy nie mogąc znieść cieżkiego i obrazliwego panowania Bolesąłwa Łysego, wnuka święty Jadwigi, ziazd sobie w Poznaniu uczyniwszy y z innymi przednimi Pany Wielgopolskimi się namowiwszy, ws dził na panstwo Przemysłąwa y Bolesłąwa, bracia, syny Włądysłąwa Plwaczem nazwanego, y tak Bracią swą Wielkie Polaki z onego nieznośnego iarzma Bolesłąwowego wyzwolił. O czym świadczą kronikarzy naszy, Miechowita y Kromer”; J. Choryński, dz. cyt., s. C2: „Ten [tzn. Mikołaj - przyp. M. H.], zrodziwszy syna Sedziwoia onego w dziełach rycerskich y cnotach Chrzescianskich tak wyćwiczył, że tesz król one bacząc wsiami bogatemi Gołaza, Biała y innymi Roku Panskiego 1245 dziedzicznym sposobem darował".

155 Postać nienotowana w źródłach. Jedyny Sędziwój piastował godność kasztelana międzyrzeckiego w czasach Bolesława Pobożnego. Zob. Urzędnicy wielkopolscy XII-XVw. Spisy, oprac. M. Bielińska, A. Gąsiorowski, J. Łojko, red. A. Gąsiorowski, Wrocław 1985, s. 53-54 (tu Sędziwój odnotowany pod nr. 275), 135-137.

156 Tablica w kościele parafialnym: I. W. Gronkowski, dz. cyt., s. 41: „także i panu Sędziwojowi z Czarnkowa, kasztelanowi międzyrzeckiemu który dziedzictwo Czarnków od króla Władysława Łokietka, aby w tem miejscu miećmieć warowniejsze punkta obronne królestwa przeciw napadom nieprzyjacielskim, na Rogożno zamienił”. De origine..., k. 112: „Tego [tj. Mikołaja wojewody - przyp. M. H.] wnuk Castellan Miedzyrzecki, aby firmior custodia ab incurssionibus Pomoeranitis haberetur, uczynil był zamiane na Rogozno”; M. Bembus, dz. cyt., s. 13: „Trzeciego wieku po tysiącznym zaczny był SĘDZIWOY, Grabia z Czarnkowa, Kasztelan Miedzyrzedzki. Z tym Władysłąw Łokietek, krol Polski, takie postanowienie uczynił. Wiodł ten Pan Anno Domini 1325 woyne z Mragrabiami Brandenburskimi. Chcąc tedy aby Zamek Czarnkowski, iako na 
wą Sędziwoja, kasztelana nakielskiego, w czasach Kazimierza Wielkiego ${ }^{157}$. Drugie wydarzenie notuje tylko autor rękopisu De origine... Jednak jego specyficzny charakter nakazuje uznać je za integralny element rodzinnej tradycji. Otóż miało wtedy dojść do sądu nad zabójcami Przemysła II. Do stawienia się przed królewskim obliczem zostali wezwani wszyscy żyjący przedstawiciele rodów Zarembów i Nałęczów. W trakcie procesu niewymieniony z imienia Czarnkowski (może ów Sędziwój, który zamienił z królem Czarnków na Rogoźno?) miał wykazać, że w czasie, kiedy został przeprowadzony zamach na Przemysła, nie było go w Polsce, przebywał bowiem w Jerozolimie u Grobu Pańskiego. Odcinał się również od związków z innymi gałęziami rodu, dowodząc, że godło, którego używa, to Nałęcz niewiązany, zwany inaczej Nałonie ${ }^{158}$. Odzyskanie Czarnkowa kończy narrację dotyczącą dziejów ro-

on czas pograniczny, w poteznieyszym był opatrzeniu, wziął od Czarnkowskiego w zamianie Czarnkow, a puścił mu Rogoźno z majętnościami”; J. Choryński, dz. cyt., s. C2: „Niegodzim się tu przepomnieć Jaśnie Wielmożnego IM Pana Sedziwoia Comitem a Czarnkow Miedzyrzeckiego Kastellana który za krola Łokietka zacne dzieła animuszu Panskiego swoiego oświadczał".

157 Tablica w kościele parafialnym: I. W. Gronkowski, dz. cyt., s. 41: „I także Sędziwojowi hrabiemu, kasztelanowi nakielskiemu, który znowu Czarnków jako siedzibę swych przodków w miejsce Rogoźna od Kazimierza Wielkiego, króla polskiego, napowrót otrzymał”; De origine..., k. 112: „Castellan Nakielsky puszcił Rogozno a Czarnkowa od krola wielkiego Kazimierza dostał”; M. Bembus, dz. cyt., s. 14: „y było to Rogoźno w domu Czarnkowskim aż do króla Kazimierza Wielkiego: od którego SEDZIWOY, grabia z Czarnkowa, kasztelan nakielski znowu otrzymał Czarnkow, wrociwszy do korony Rogoźno. Na co maią Panowie z Czarnkowa przywiley tegoż króla y rozmaite w nim wolności, tak sobie, iako y swoim poddanym pozwolone. Przywiley ten tak się zaczyna: Nos Casimirus Dei gratia Rex Poloniae; Dominium vel Regnum nostrum in vtilitatibus quibuslibet ampliatre cupientes, seruitiaq[ue] fidelia et grata nobis per fidelem nostru[m] Sandiuogiu[m], Comitem a Czarnkow, multipliciteret constante exhibita, et in futurum exhibenda considerantes. Volentes itaq[ue] meritis eiusdem Sandiuogii gratijs regalibus respondere, \&c. ex tunc castrum nostrum Czarnkow dictum, \&c. pro haeredatibus suis videlicet Rogozno, \&c per modum commutationis damus, tradimus, conferimus, \& donamus in perpetuum \&c. Actum Posnaniae in octaua S. Trinitatis Anno Domini 1343”; J. Choryński, dz. cyt., s. C2: „Także Jasnie wielmoznego IM Pana Sedziwoia kasztelana nakielskiego, który za Rogosno Czarnkow przemieniwszy dziedziczno maietnosc potomkom swym zostawił".

158 De origine..., k. 112: „tedy ztąd się pokazało, a mianowicie z Decretu Krola Wladisława L'okietkta in Iudicys magnis Regis, Datum in Campis circa Suleiow celebratis, na które te wielkie Sądy byly zpoziwani familiar[es] Nalecz et Zaremba,wszisci accurati necis Przemyslai Regis Poloniae in Rogosno occisi, tam Czarnkowsky albo iako pisano de Czarnkow Comes stanął y pokazał autentica, ise w Polscze niebyl na ten czas, ale w Jeruzalem, u grobu Panskiego, Pokazał tez to, ze nie jest nałęnczanin związaney na- 
dziny zapisaną na brązowej tablicy. Dalsze jej losy znajdują odzwierciedlenie jedynie w mowie pogrzebowej autorstwa M. Bembusa oraz w anonimowym De origine... Jednak dla drugiej połowy XIV stulecia obie prace uwzględniły inne wydarzenia. W rozprawce De origine... odnotowano rzekome pokrewieństwo Czarnkowskich z podkanclerzym Kazimierza Wielkiego, Jankiem z Czarnkowa, uznanym za syna Sędziwoja, kasztelana nakielskiego ${ }^{159}$. Dla Bembusa ważniejszy był natomiast fakt podziału dóbr czarnkowskich, którego mieli dokonać Sędziwój, kasztelan nakielski, z synami Janem i Wincentym, o czym dowiedział się zapewne z jednego z czarnkowskich falsyfikatów, oraz informacja o wojnie Czarnkowskich ze Świętoborem, księciem pomorskim $^{160}$. Opisu tego drugiego wydarzenia, podanego przez Bembusa za Kronika Janka z Czarnkowa, nie należy chyba włączać do kanonu tradycji rodzinnej, a potraktować raczej jako wyraz erudycji poznańskiego kaznodziei. Opowieść o początkach Czarnkowskich obaj autorzy kończą jednak w tym samym momencie: przedstawiając udział Jana Czarnkowskiego w zasadzce na posłów cesarskich wiozących koronę Witoldowi ${ }^{161}$. Ów fragment dziejów

łęnczy, którą to zwiazaną nałęcz zwano nodosam, y wywodził originem et genealogiam suam a Dorzycraio D[omin]no Czlapensi, którego Chabry Bolesław krol na wiarę na wrócił [!] Chrzescianską y okrzcił. Zaniechawszy swego herbu Poganskiego [...], a uprosził za Herb owę chustkę, którą Pan Christus na krzizu był przepasan, y nazwano to sinule alias nałonie, et postea mutato uel corrupto nałęcz nazwano".

159 De origine..., k. 112v: „którego Castellana Nakielskiego za Kazimierza Wielkiego był syn Podkanclerzym Koronnym qui statuit Priuilegium Mon[ast]erio Tremesnens[i] v Krakowa Datum per manus Joannis de Czarnkow, Vicecancellary Regni nostri. Te drugie Prziuileie ktorem tu mianował, a to tak Pan Bóg zdarził, zem ia był wział do siebie z ony gromady listow, w Szubinie pogorzałych et hanebtr[?] et demonstrari possunt".

160 M. Bembus, dz. cyt., s. 14: „Tenże Pan nakielski między dwoma synami swemi, Ianem y Wincentym dóbr swoich dział uczynił, w którym się też kłądzie Szłopa. A ten dział przerzeczony Kazimierz król Anno 1362 potwierdził, y przywilejami warował, gdzie się też niemałe maiętności teyże familiey w margrabstwie brandenburskim mianuią. Tegoż wieku, iako Kromer pisze, za Ludwika Polskiego y Węgierskiego Króla Sendziwoy Czarnkowski, kasztelan bninski z Janem, synowcem swoim, Sedziego Poznańśkiego synem, woiowali Swantoborza, ksiązę szczecinskie. Ten zebrawszy się na nie mocą ich w oyczystym Szłopienskim zamku, dobywał: ale daremnym zaciągiem lud swoy spracowawszy y wiele dzielnego rycerstwa ztraciwszy, nic sprawić nie mogąc odciągnać musiał, co się działo roku Panskiego 1379”. Szerzej na temat tych wydarzeń zob. J. Zdrenka, Polityka zagraniczna ksiażąt szczecinskich w latach 1295-1411, Słupsk 1987, s. 201-202.

161 De origine..., k. 112v: „tym tempore Wladislai Jagiellonis Joannes de Czarnkow Comes, syn tego Podkanclerzego, bedącz Podkomorzym Poznanskim poimał wpuszczy, gdy się przekradali posłowie Cesarza Zygmunta którzy Witultowi Wielkiemu Xciu Li- 
rodziny z relacji Kromera zna zarówno Bembus, jak i Choryński. Ten drugi jednak aktora owych wydarzeń, Jana Czarnkowskiego, podkomorzego poznańskiego, nie wymienia w poczcie wybitnych przodków Adama Sędziwoja. Natomiast zasadzka pod Turzą Górą posłużyła mu jedynie jako exemplum poświęcenia rodziny dla ojczyzny i zaufania, jakim darzyli jej przedstawicieli władcy Polski ${ }^{162}$. Przy tym tak jak Bembus i Choryński opisują to wydarzenie dość lakonicznie, raczej wiernie powtarzając kronikarską relację, tak autor De origine... uczynił z Jana Czarnkowskiego niemal zbawiciela ówczesnej Polski, zapobiegającego rozbiciu unii polsko-litewskiej i inkorporacji Litwy do cesarstwa. Dalszy ciąg narracji, zarówno w De origine..., jak i u Bembusa oraz Choryńskiego, to typowe dla nowożytnych prac genealogicznych wymienianie przedstawicieli kolejnych pokoleń rodziny, ich koligacji i osiągnięć.

Zrekonstruowana powyżej tradycja o początkach Czarnkowskich nie ma więc charakteru linearnego. Stanowi raczej zbiór mniej lub bardziej prawdo-

tewskiemu niesli Coronę y Przywiley na krolestwo Litewskie, wziął tez przy tem przy Poslech Litewskich dwa Przywileia pergaminowe z pieczenciami zawieszonemi Witulta y niektorych Panow Litewskich incorpor[atio]onis Lithuaniae ad Regnu[m] Romanum iest przywiley tego opisano magnis laudibus ad caelum extollunt,. A praemium zato ogon pawi a strzała przezeń na Hełmie miedzi rogami Jelenimi. O Boze wszechmogaczy chciano by teraz za to miast, zamkow, imion a czoz wiedzieć"; M. Bembus, dz. cyt., s. 15: „Czwartego wieku wspomina tenże Historyk [tj. M. Kromer - przyp. M. H.], w 50 lat potym, Jana Czarnkowskiegom Podkomorzego poznańskiego. Temu król Jagiełło, cnocie i czułości iego doznaney dufaiąc, poruczył, aby na pograniczu Polskim i Margrabstwie, gdzie wielkie maiętności swoie miał, posłańce Cesarskie y Witułdowe przez Pruską ziemie tam y samw prektykach pewnych Koronie Polskiey barzo niebezpiecznych y szkodliwych przeziezdzaiące. Czuyną straż rozsadziwszy przeymował. Co mu się dobrze nadało, bo posły poimał, wytrząsnął y przeiete u nich pisma Krolowi Panu swemu posłał, od któego znacznie iest vczczony y udarowany y w dalszey łąsce upewniony”. J. Choryński, dz. cyt., s. C6: „gdy zanienawiscią a poduszczeniem Cesarskim Witułt zazdroszcząc szcześliwego Panownia Krola Jagiela Korone sobie Litewską gotował, kto temu mądrą radą y waleczną potęgą zabieżał? Słuchaycie Kromera lib. 19. Wiedząc mówi o dzielnosci a sczerości Jana Czarnkowskiego, Podkomorzego Poznańskiego polecieł mu aby on przestrzegał tego aby Korony niedopuszczał do Państwa przywozić nieomyleł się na posłudze i sczerości iego: Jagieło, wnet bowiem na granicy z odwagą zastąpiwszy Baptiste Cigule mistrza wprawie Gniewskiego y Zygmunta Rota Slezaka poimawszy listy odebrawszy Krolowi odesłał". Szerzej na temat owych wydarzeń zob.: K. Górska-Gołaska, Zasadzka rycerstwa wielkopolskiego na drodze margrabskiej pod Turza Góra w 1430 r., Studia i Materiały do Dziejów Wielkopolski i Pomorza, t. 23, 1976, s. 53-62; G. Błaszczyk, Dzieje stosunków polsko-litewskich, t. 2: Od Krewa do Lublina, cz. 1, Poznań 2007, s. 505-582, szczególnie s. 559-563, gdzie autor analizuje wydarzenia związane z zasadzką wielkopolskiego rycerstwa.

162 J. Choryński, dz. cyt., s. C6. 
podobnych wydarzeń, godnych, z punktu widzenia rodziny, zapamiętania. Próby „załatania” owych luk zostały podjęte dopiero przez nowożytnych erudytów, a ich celem miało być stworzenie bardziej płynnej, a zatem bardziej prawdopodobnej opowieści.

Dla analizy przekazu zawartego na pieczęciach Adama Sędziwoja Czarnkowskiego istotne jest to, że tradycji rodowej towarzyszy tradycja heraldyczna ${ }^{163}$. Wzmianki o genezie poszczególnych elementów herbu występują obok fragmentów opowieści, niejako otwierających i zamykających rodowe „dzieje bajeczne”. Historię rodziny Czarnkowskich otwiera opis przyjęcia chrztu przez protoplastę rodu. Jak już zauważono, inaczej niż w drukowanych herbarzach, źródła związane z Czarnkowskimi datują to wydarzenie konsekwentnie na czasy panowania Bolesława Chrobrego ${ }^{164}$. Właśnie z chrztem Dzierżykraja człopskiego ma wiązać się geneza herbowego godła Czarnkowskich. Według wersji zanotowanej przez autora pracy De origine... po chrzcie pan na Człopie miał poprosić władcę Polski o zmianę dotychczas używanego herbu. Swym godłem chciał uczynić chustę, którą był przewiązany Chrystus na krzyżu. Stąd też miała się wziąć pierwotna nazwa herbu: Nałonie. Dopiero później mutato vel corrupto herb ów miał przyjąć nazwę Nałęcz ${ }^{165}$. Nieco inną wersję legendy podaje Paprocki. Według niego godłem herbowym Nałęczów miała stać się chusta, zawiązana po chrzcie przez władcę Polski na głowie książęcego chrześniaka. Istotny dla nas jest zaakcentowany już wyżej fakt podkreślania odmienności herbowego godła, wówczas już zapewne archaicznego. Powodowało to, że legenda herbowa związana z Dzierżykrajem człopskim była przez Czarnkowskich niejako zawłaszczana. Skoro bowiem to ich przodek, a Człopa leżała przecież w kompleksie nadnoteckich dóbr Czarnkowskich, miał otrzymać godło, którego używali wszyscy jego potomkowie, to jedynym właściwym godłem dla herbu Nałonie (bądź Nałęcz) jest to, znajdujące się w herbie rodziny. Inne rody, posługujące się odmienionym godłem, jawią się jako uzurpatorzy legendy herbowej.

Interpretację kompozycji heraldycznej znajdującej się na pieczęci Adama Sędziwoja Czarnkowskiego ułatwia jeszcze jedna informacja, podawana przy okazji relacji o chrzcie Dzierżykraja, mianowicie opis jego pogańskiego her-

163 O zespołach herbów mających prezentować „świadomość genealogiczną” społeczeństwa staropolskiego zob. M. Koczerska, Świadomość genealogiczna możnowtadztwa polskiego w XV wieku. Podstawy i środki wyrazu, Społeczeństwo Polski Średniowiecznej, t. 2, 1982, całość.

164 Zob. B. Paprocki, Gniazdo, s. 21; tenże, Herby rycerstwa polskiego, s. 207; K. Niesiecki, dz. cyt., s. 206, którzy datują to wydarzenie na czasy Mieszka I.

165 De origine..., k. 112. 
bu. W tym przypadku zarówno tradycja rodowa, jak i późniejsi heraldycy są zgodni. Na tarczy herbowej księcia człopskiego miała znajdować się porfirowa kolumna podtrzymywana przez dwa gryfy ${ }^{166}$. Wątki heraldyczne pojawiające się w opowieści o dziejach Czarnkowskich kończy wyjaśnienie genezy odmienionego klejnotu herbowego. Według autora De origine... ów „ogon pawi a strzała przezeń na Hełmie miedzi rogami Jelenimi” miał być nagrodą za udział Jana Czarnkowskiego w zasadzce na posłów wiozących koronę Witoldowi.

Wróćmy zatem do pieczęci Adama Sędziwoja Czarnkowskiego. Płaszczyzną, na której będziemy budowali interpretację wizerunków napieczętnych i inskrypcji z pieczęci Adama Sędziwoja, będzie założenie znajomości i utożsamiania się przezeń z tradycją rodową. Na przyjęcie tego warunku pozwala z jednej strony widoczna aktywność młodszej linii rodu w kształtowaniu tejże tradycji, z drugiej zaś hipoteza łącząca autorstwo, a przynajmniej znajomość treści, przywoływanego tu często rękopisu De origine... z Adamem Sędziwojem Czarnkowskim. Wychodząc z tych założeń oraz biorąc pod uwagę tradycję rodową i heraldyczną Czarnkowskich, można uznać, że kładziony na tarczy herbowej znak jawi się jako ośrodek, wokół którego krystalizowała się tożsamość rodziny. Działo się tak przez rzadkość niewiązanej odmiany godła w stosunku do przewiązanej wersji Nałęcza ${ }^{167}$. Jednocześnie samo godło miało wskazywać na dawność rodu, a towarzyszący tarczy herbowej klejnot stawał się, w świetle tradycji rodowej, świadectwem zasług Czarnkowskich dla Rzeczypospolitej. Uzupełnieniem przekazu ikonicznego była inskrypcja napieczętna. Pojawiają się w niej dwa specyficzne elementy, wymagające osobnego omówienia. Chodzi o drugie imię oraz nazwisko naszego magnata. W przypadku rodziny Czarnkowskich drugie imię Sędziwój stało się przydomkiem używanym przez niemal wszystkich potomków Sędziwoja Czarnkowskiego i Barbary Pampowskiej. Co ciekawe, zespół falsyfikatów czarnkowskich stwarzał przesłanki dla uznania, że z osobami noszącymi to imię wiązały się szczególne zasługi. Druga rzecz to charakterystyczna forma nazwiska, pojawiająca się w legendzie pieczęci przedstawicieli młodszej linii Czarnkowskich. Jak się wydaje, to zamierzony zabieg, mający na celu „oczyszczenie” go z późniejszych naleciałości. Nie było to może tak mocno akcentowane jak kwestia herbowego godła, niemniej jednak miało słu-

166 Tak De origine..., k. 112; K. Niesiecki, dz. cyt., s. 205. Niesieckiemu przekaz o gryfach w herbie Dzierżykraja dał asumpt do powiązania ich z potomkami mitycznego Leszka, którzy mieli pieczętować się właśnie gryfem w różnych odmianach.

167 Zob. przyp. 95. 
żyć temu samemu celowi: podkreśleniu własnej odrębności oraz wskazaniu na „starożytną genealogię”. Nie bez kozery autor De origine... zaznacza, że w czasach, kiedy jego przodek bronił honoru Czarnkowskich przed oskarżeniem o udział w zamachu na Przemysła II, nazwisko rodziny brzmiało de Czarnkow, a nie Czarnkowski ${ }^{168}$.

Herb złożony umieszczony na pieczęciach większych Adama Sędziwoja zalicza się do tej stosunkowo rzadkiej grupy, która wymyka się standardowym regułom interpretacji, traktującym taki typ herbu jako wywód genealogiczny pozwalający na weryfikację szlachectwa. Wydaje się więc, że znaczenia tej kompozycji należy szukać gdzie indziej. Poruszamy tu problem symboliki kompozycji heraldycznych, rozwijającej się w epoce nowożytnej pod wpływem m.in. emblematyki ${ }^{169}$. Na najprostszą interpretację tego znaku wskazuje zestawienie go z legendą pieczęci. Wspomniano już, że w skwadrowanym polu większego herbu Adama Sędziwoja umieszczono godła Czarnkowskich i Pampowskich. Ta konstrukcja pełni funkcję zbliżoną do tej, jaką pełni drugie imię w legendzie, określając, przez herby protoplastów, linię rodu, z której Adam Sędziwój pochodził.

Ciekawą możliwość rozumienia tej kompozycji stwarza informacja, że pierwotnym herbem Dzierżykraja z Człopy była kolumna podtrzymywana przez dwa gryfy. Przypomnijmy, że na pieczęci Czarnkowskiego również dwa gryfy podtrzymują tarczę herbową. Jeśli byłoby to nawiązanie do heraldyki mitycznego protoplasty rodziny, to wówczas ujmowana przez heraldyczne bestie tarcza herbowa mogłaby być utożsamiana z kolumną z herbu Dzierżykraja. Kolumna zaś to wyraz siły i trwałości ${ }^{170}$. A zatem przekaz wskazywałby na przodków (przez godło Nałęcza na mitycznego Dzierżykraja, a przez skwa-

168 De origine..., k. 112: „na które te wielkie Sądy były zpoziwani familiar[es] Nalecz et Zaremba, wszisci accurati necis Przemyslai Regis Poloniae in Rogosno occisi, tam Czarnkowsky albo iako pisano de Czarnkow Comes stanął".

169 J. Pelc, Stowo i obraz. Na pograniczu literatury i sztuk plastycznych, Kraków 2002, s. 309-350. O symbolice herbów w kontekście „ideologii klejnotu” zob. M. Kazańczuk, Staropolskie legendy, s. 86, 90; tenże, O herbach szlacheckich $w$ dawnej Polsce, Nauka, nr 4, 2006, s. 117-127. Najdobitniej wyraził to A. Wyrobisz, Mowa herbów. Herby w kaplicy Kościeleckich w Kościelcu k. Inowroctawia, [w:] Arx felicitatis. Księga ku czci Profesora Andrzeja Rottermunda w sześćdziesiąta rocznice urodzin od przyjaciót, kolegów i wspótpracowników, red. J. A. Chrościcki i in., Warszawa 2001, s. 587, pisząc: „[Herby] prezentowane na nagrobkach, w kaplicach grobowych, w detalach architektonicznych budowli sakralnych i świeckich otwierały przed widzami i odbiorcami świat legend herbowych z całym bogactwem ich wątków historycznych i parahistorycznych, ideałów moralnych i wzorców osobowych".

170 D. Forstner, Świat symboliki chrześcijańskiej. Leksykon, Warszawa 2001, s. 381. 
drowanie z Poronią na Sędziwoja Czarnkowskiego i Barbarę Pampowską), na których opiera się świetność rodu. Świetność, dodajmy, która wyniosła samego Adama Sędziwoja. Stanowiłoby to wyraźne podkreślenie zasług minionych pokoleń kosztem dysponenta pieczęci. Jest to jednak wrażenie złudne, mamy tu bowiem do czynienia z konstrukcją analogiczną do figury retorycznej zwanej deminutio - dzięki niej przez pomniejszanie swoich zasług uzyskuje się efekt wyeksponowania własnej osoby ${ }^{171}$. Na marginesie warto zauważyć, że już zestawiając elementy herbu powiązane z opowieścią o dziejach Czarnkowskich, dokonano, skrótowej co prawda, prezentacji owej tradycji: gryfy i niewiązana pomłość odwoływały się do osoby człopskiego Dzierżykraja, przeszyty zaś strzałą klejnot stanowił oczywiste odniesienie do wypadków pod Turzą Górą. Jednocześnie forma herbu wskazywała na rzeczywiste aspiracje Czarnkowskiego. Symptomatyczne jest odwoływanie się do rozwiązań znanych z zachodnioeuropejskich herbów wykorzystywanych przez szlachtę tytularną. Ów kształt kompozycji heraldycznej koresponduje z tytulaturą, używaną przez Adama Sędziwoja w latach dwudziestych XVII w., w której owe zakotwiczone w tradycji rodzinnej aspiracje ${ }^{172}$ znalazły swe odzwierciedlenie. Wówczas zaczął on tytułować się księciem na Człopie i hrabią na Czarnkowie. W sferze wizualnej najpełniejszy wyraz znalazły one w wystroju czarnkowskiej fary, gdzie na ozdobnych kratach zamykających wejścia do kaplic bocznych znajdują się wyobrażenia Nałęcza zwieńczone książęcą mitrą. Mimo że sam znak został przemalowany w latach późniejszych, to jego forma pochodzi z pierwszej połowy XVII w. ${ }^{173}$

\section{ZAKońCZenIE}

Zespół pieczęci Adama Sędziwoja Czarnkowskiego, mimo że nie zachował się w komplecie, pozwala na analizę systemu sfragistycznego jednego z przedstawicieli wielkopolskiego możnowładztwa. Jest to jednak zbiór specyficzny. Wydaje się on nienaturalnie rozbudowany w stosunku do zespołów pieczęci nawet zamożniejszej szlachty. Na system sfragistyczny Czarnkowskiego składały się bowiem pieczęcie urzędnicze potrzebne do funkcjono-

171 M. Barłowska, Jerzy Ossolinski, orator polskiego baroku, Katowice 2000, s. 123. Na związki nowożytnej heraldyki z retoryką zwraca uwagę M. Kazańczuk, O herbach, s. 117-127, szczególnie s. 119-120.

172 J. Choryński pisze o Adamie Sędziwoju jako o „xiążęciu z przodków swoich na Człopie”. J. Choryński, dz. cyt., s. C6.

173 Katalog zabytków Czarnków, s. 4, fot. 5. 
wania samego urzędu starosty generalnego, a także podległych mu urzędów grodzkich, oraz pieczęcie osobiste, wśród których można też wyróżnić kilka podtypów. Ów rozrost był spowodowany przede wszystkim piastowaniem przezeń godności starosty generalnego Wielkopolski, do obsługi której wykorzystywano aż siedem z dziewięciu znanych typów pieczęci Czarnkowskiego. Pokazuje to, jak duży wpływ na kształt systemu sfragistycznego szlachty miały sprawowane przez daną osobę urzędy. Pozwala też na twierdzenie, że kształt systemu sfragistycznego szlachcica był wypadkową jego pozycji społecznej oraz liczby zajmowanych przezeń stanowisk.

Przez ikonografię i inskrypcję napieczętną pieczęcie Czarnkowskiego włączały się do staropolskiego systemu komunikacji społecznej. Umieszczane na stemplach napisy umożliwiały nie tylko identyfikację dysponenta, ale też wskazywały na kompetencje pieczęci. Stało się to szczególnie istotne po reformie sądownictwa grodzkiego w Wielkopolsce, kiedy to kompetencje surogatorów grodu kaliskiego i poznańskiego obejmowały wyłącznie określone powiaty. Jednak głównym środkiem przenoszenia informacji był herb, pozwalający na przekazywanie całkiem skomplikowanych treści.

Dzięki funkcjonowaniu pieczęci Czarnkowskiego na styku przestrzeni publicznej i prywatnej są one nie tylko źródłem informacji o dziejach urzędów starościńskich, ale też, przez swą ikonografię, pozwalają wniknąć w świat ideologii szlacheckiej i związanej z nią symboliki. W naszym przypadku na pieczęciach Adama Sędziwoja Czarnkowskiego za pomocą herbów została zakodowana legenda herbowa używanej przez rodzinę odmiany Nałęcza. Jej narracja wykształciła się zapewne w pierwszej połowie XVI w. i pozostawała w jakimś związku ze sprawą czarnkowskich falsyfikatów. Z drugiej strony, umieszczone na pieczęci wyobrażenie odwoływało się do aspiracji magnata, który, według legendy, mając książęcych przodków, sam zaczął uważać się za księcia.

\section{The seals of Adam Sędziwój Czarnkowski, the general starost of Grand Poland}

Summary

Adam Sędziwój Czarnkowski descended from an old noble family with origins in Grand Poland that can be traced back to at least the first half of the fourteenth century. He belonged to the younger family line started by Sędziwój Czarnkowski, the castellan of Przemęt (his brother, Maciej, is considered to be the progenitor of the older line), a son of Sędziwój, the voivode of the Poznań, and a grandson of Jan, the castellan of Gniezno. 
Adam was a grandson of Sędziwój and a son of Wojciech Sędziwój Czarnkowski, the general starost of Grand Poland, and Jadwiga Sierpska from Gulczewo of the Prawdzic coat-of-arms, the daughter of the voivode of Rawa. As a reward for his contribution to the wars with Russia, he was appointed the starost of Pyzdry by King Stefan Batory in 1579. At the same time, he inherited the title of the commander of the Knights of Saint John in Poznań (komandor poznańskich joannitów) from his father. During the reign of king Sigismunt III, he was a supporter of the king. It was during that time that his career proceeded quickly: in 1593 he became the general starost of Grand Poland, and in 1606 he was appointed the voivode of Łęczyca.

Not all of Adam Sędziwój Czarnkowski's seals survived to this day, but those remaining allow the analysis of the sigillographic collection of one of the oligarchs of Grand Poland. This collection, however, is specific. It seems to be unusually numerous when compared to the seal collections that belonged to other, even the richest, noblemen. That is because Czarnkowski's collection included official seals necessary to carry out the duties of the general starost and other, lower posts, e.g. those related to governing a castle court and office (urzad grodzki), as well as personal seals, which can be divided into several sub-categories. The collection grew mostly because Czarnkowski held the office of the general starost of Grand Poland and this required using seven, out of nine, known types of Czarnkowski's seals. It shows to what a great extent the seal collections of noblemen were influenced by the offices they held. It also allows the author to state that a seal collection of a nobleman reflected his social status and the amount of offices he held. The images and inscriptions on Czarnkowski's seals were part of the communication system present in Poland at the time. The words inscribed in the seals not only allowed the identification of an official but also his competence. This became particularly important after the judicial reform (reforma sadownictwa grodzkiego) in Grand Poland, when the competence of the deputy starost of Kalisz and Poznań covered only selected districts. However, it was the coat-of-arms that was the main medium for conveying information and that allowed the transferring of quite complex messages. Because Czarnkowski's seals functioned on the verge of the private and public spheres, they not only provide a lot of information about the history of the starost office, but through their images they also give us an insight into the world of ideology of the nobility and its related symbols. In this case, the coat-of-arms on Adam Sędziwój Czarnkowski's seals helped encode the legend of this version of the Nałęcz coat-of-arms that was used by his family. Its design emerged probably around the first half of the sixteenth century and had something to do with the case of forgeries (czarnkowskie falsyfikaty). However, the images on the seal can be also interpreted as referring to the aspirations of the magnate who, according to a legend, had royal ancestors and began to think of himself as a prince as well. 